\title{
5. PETROLOGY AND GEOCHEMISTRY OF BASALTS FROM THE VAVILOV BASIN (TYRRHENIAN SEA), OCEAN DRILLING PROGRAM LEG 107, HOLES 651A AND 655B ${ }^{1}$
}

\author{
H. Bertrand, ${ }^{2}$ P. Boivin,${ }^{3}$ and C. Robin ${ }^{3}$
}

\begin{abstract}
During ODP Leg 107, two holes were drilled in the basement of Vavilov Basin, a central oceanic area of the Tyrrhenian sea. Hole 655B is located near the Gortani ridge in off-axis position at the western rim of the basin; Hole $651 \mathrm{~A}$ is located on a basement swell at the axis of the basin. This paper deals with mineral chemistry, major and trace element geochemistry, and petrogenesis of the basalts recovered in the two holes.

The mineralogy of the basalts is broadly homogeneous, but all of them have suffered important seawater alteration. Their major-element compositions are similar to both normal-mid-ocean-ridge-basalts (N-MORB) and back-arc-basalts (BAB) except for $\mathrm{Na}_{2} \mathrm{O}$ contents (BAB-like), and $\mathrm{K}_{2} \mathrm{O}$ which is somewhat enriched in upper unit of Hole 651A. Their affinity with $\mathrm{N}-\mathrm{MORB}$ and $\mathrm{BAB}$ is confirmed by using immobile trace elements such as $\mathrm{Zr}, \mathrm{Y}$, and $\mathrm{Nb}$. However, basalts from the two sites present contrasting geochemical characteristics on spidergrams using incompatible elements. Hole 655B basalts are homogeneous enriched tholeiites, similar to those from DSDP Hole 373 (located on the opposite side of the basin near the eastern rim), and show affinities with enriched MORB (E-MORB). At Hole 651A, the two basalt units are chemically distinct. One sample recovered in lower unit is rather similar to those from Hole 655B, but basalts from upper unit display calc-alkaline characteristic evidenced by the increase of light-ion-lithophile-element (LILE)/ high-field-strength-element (HFSE) ratio, and appearance of a negative $\mathrm{Nb}$-anomaly, making them comparable with orogenic lavas from the adjacent Eolian arc. The observed chemical compositions of the basalts are consistent with a derivation of the magmas from a N-MORB type source progressively contaminated by LILE-enriched fluids released from dehydration of the bordering subducted plate.

Implications for evolution of the Tyrrhenian basin are tentatively proposed taking into consideration geochemical and chronological relationships between basalts from Leg 107 Holes 655B and 651A, together with data from Leg 42 Site 373 and Vavilov seamount. These data illustrate back-arc spreading in ensialic basin closely associated with the maturation of the adjacent subduction, followed by the growth of late off-axis central volcano, whereas the active subduction retreats southeastward.
\end{abstract}

\section{INTRODUCTION}

\section{Geological Setting}

Developed in a general collisional context, the Tyrrhenian Sea is a small triangular sea surrounded by the Sardinian continental margin, the Eolian volcanic arc, and the Italian Peninsula (Fig. 1). Its central basin is considered to be back-arc basin (Boccaletti and Guazzone, 1972; Barberi et al., 1973, 1978) that has opened behind a still active subduction zone. Subduction is evidenced by northwestward deepening of seismic foci along the Benioff plane (Gasparini et al., 1982) and by the orogenic volcanism of Eolian islands (Barberi et al., 1974; Keller, 1974; Beccaluva et al., 1985). Evolution of the back-arc spreading is presumably linked to the southeastward migration of the Calabrian-Sicilian arc system, probably in response to complexities in subduction of the Ionian lithosphere (Moussat, 1983; Moussat et al., 1985; Kastens et al., 1986; Rehault et al., 1987). The main rifting phase started during the Tortonian and led, around the early Pliocene, to the creation of a narrow central oceanic area subdivided into two basins, the Vavilov Basin and the Marsili Basin (Rehault et al., 1987). These two basins are thought to be diachronous, possibly as an effect of the retreat toward the southeast of the subduction zone (Kastens et al., 1986). Geo-

\footnotetext{
${ }^{1}$ Kastens, K. A., Mascle, J., et al., 1990. Proc. ODP, Sci. Results, 107: College Station, TX (Ocean Drilling Program).

${ }^{2}$ Laboratoire de Pétrologie, Unité Associée no. 726 C.N.R.S.-E.N.S. Lyon, 46 allèe d'Italie, 69364 Lyon Cedex, France.

${ }^{3}$ Unité Associée no. 10 C.N.R.S.-Université, et Centre de Recherches Volcanologiques (CRV), Université Clermont II, 5, rue Kessler, 63038 ClermontFerrand Cedex, France.
}

physical studies indicate that the basement of the basins is oceanic-type lithosphere (Steinmetz et al., 1983; Recq et al., 1984; Della Vedova et al., 1984; Hutchison, 1983). These data are corroborated by petrological and geochemical investigations made on basalts recovered at DSDP Site 373, which show an oceanic tholeiite affinity (Dietrich et al., 1977; Barberi et al., 1978), with some "transitional" characteristics (Hamelin et al., 1979). Moreover, in each basin, the abyssal plain is dominated by a voluminous central volcano elongated parallel to the axis of the basin. They are Vavilov and Marsili seamounts. Lavas from Vavilov have been described as tholeiitic/transitional basalts (Selli et al., 1977; Beccaluva et al., 1982), to mildly alkaline basalts independent of the surrounding oceanic crust (Robin et al., 1987).

During Leg 107, two holes were drilled in the basement of Vavilov Basin. Hole 651A is located on a ridge in the axis of the basin, in a water depth of $3578 \mathrm{~m}$. This ridge extends on strike of Vavilov seamount, and is considered as an embryonic center of accretion (Kastens et al., 1986). Hole 655B is located on the north-south Gortani ridge (water depth $3290 \mathrm{~m}$ ) which lies in an off-axis position to the Sardinian margin, near the transition between oceanic and continental lithosphere. This site is nearly symmetrical to Hole 373 of Leg 42 with respect to the axis of the basin.

\section{Objectives}

The first aim of this study is to characterize and compare the petrology and geochemistry of lavas recovered in Holes 651A and $655 \mathrm{~B}$, and to compare them with other lavas from Hole 373 and Vavilov seamount. These combined data are used to examine the problem of space-time relationships of magma genesis within Vavilov Basin. 


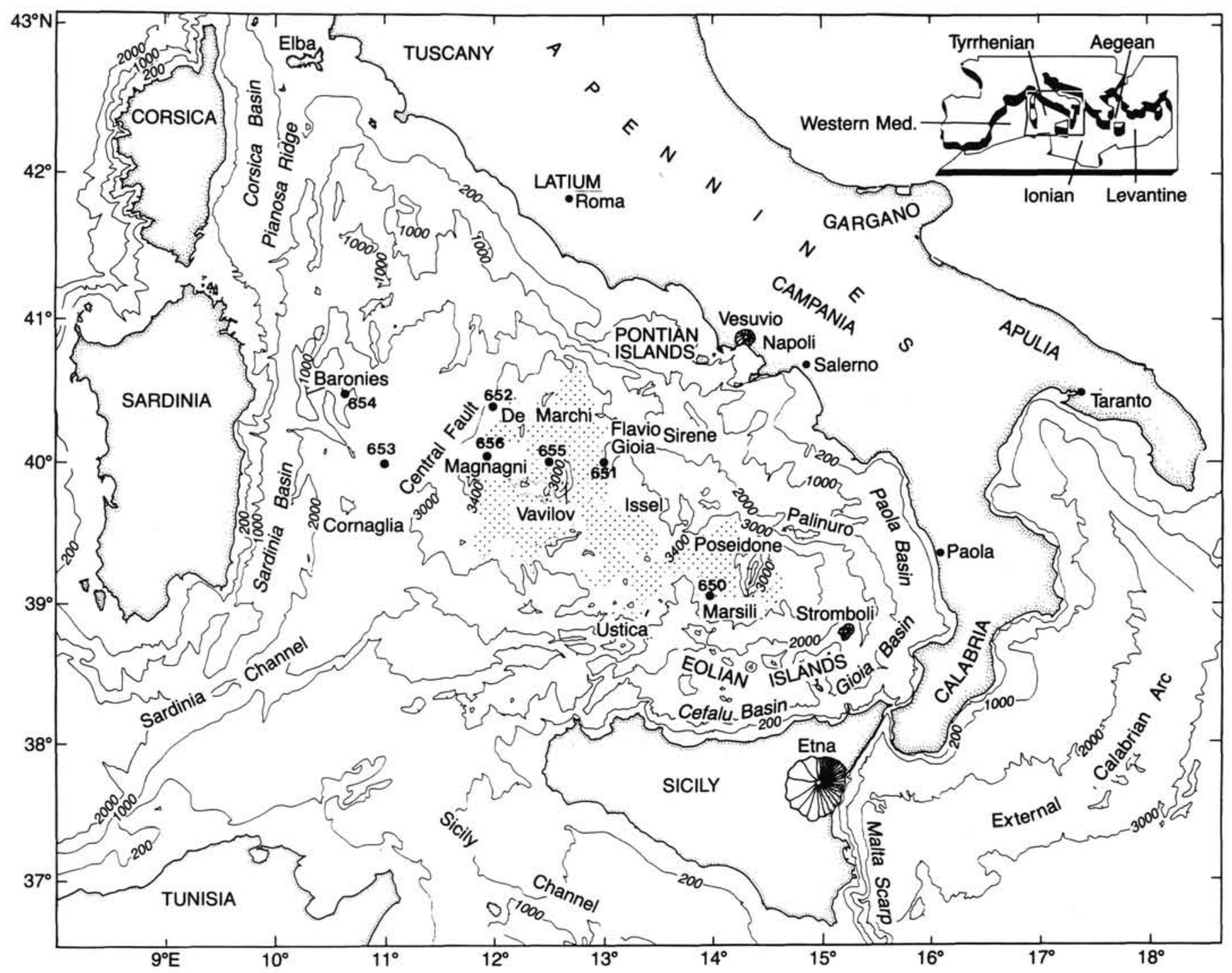

Figure 1. Location map of drill sites in basement of the Vavilov Basin: ODP Leg 107 (Holes 651A and 655B); DSDP Leg 42 (Site 373). Stippled area corresponds to central oceanic type basins.

The second goal is to compare the composition of these rocks with those erupted in rather similar tectonic environments, i.e., well established back-arc basins from the Pacific, and with mid-ocean-ridge basalts (MORB) resulting from accretion in wide oceans. These comparisons raise basic questions about magma genesis in the Vavilov Basin. Are the lavas typical of back-arc basins? Is there a distinction between lavas erupted within back-arc basins formed along continental margins (Tyrrhenian case) and in intra-oceanic basins (majority of West $\mathrm{Pa}$ cific cases)? How does magma genesis in back-arc extension environments compare with that occurring during sea-floor spreading in wide oceans? Finally, what are the implications on geodynamic history of the Tyrrhenian basins?

\section{Sampling and Analytical Methods}

Samples from Hole 655B were shared out regularly throughout the homogeneous 115 -m-thick igneous basement. Only too obviously altered parts were excluded (Fig. 2). The data presented here are quite representative of Hole 655B. For Hole 651A, only a few samples from basaltic units 1 and 3 were available, from a complex 134-m-thick basement sequence. Doleritic unit 2 and peridotitic unit 4 were not studied here (see Bonatti and Seyler, this volume).
The complete set of analytical and petrographical methods could not be applied on every sample because of limited quantities of rock. Mineral compositions were determined with the CAMECA Automatized Microprobe at the Centre de Mesures Physiques (Clermont-Ferrand University) using mineral standards supplied by the BRGM (Orléans). The operating conditions were: $15 \mathrm{kV}$ accelerating potential, 10 $\mathrm{nA}$ beam intensity, and $10 \mathrm{~s}$ count time.

Major elements were measured by atomic absorption at the Laboratory of Geology, Clermont-Ferrand University. Whole-rock standards were supplied by the Centre de Recherches Pétrographiques et Géochimiques (CNRS, Nancy). Trace elements ( $\mathrm{V}, \mathrm{Cr}, \mathrm{Co}, \mathrm{Ni}, \mathrm{Rb}, \mathrm{Sr}, \mathrm{Zr}$, $\mathrm{Nb}$, and $\mathrm{Y}$ ) were determined at the Laboratory of Petrology of Lyon University by X-Ray-Fluorescence. Rare-earth elements were determined by inductively coupled plasma-emission spectroscopy at the CRPG (Nancy).

\section{PETROGRAPHY AND MINERAL CHEMISTRY}

The main petrographic characteristics are summarized in Table 1 . All the studied samples are of basaltic composition. In all basalts from the two sites, textures are moderately porphyritic, with the groundmass ranging from microlitic to glassy, often with quench crystals. An exception is rock D (651A, core 49R-1, 132-134 cm), which exhibits a doleritic texture. This 


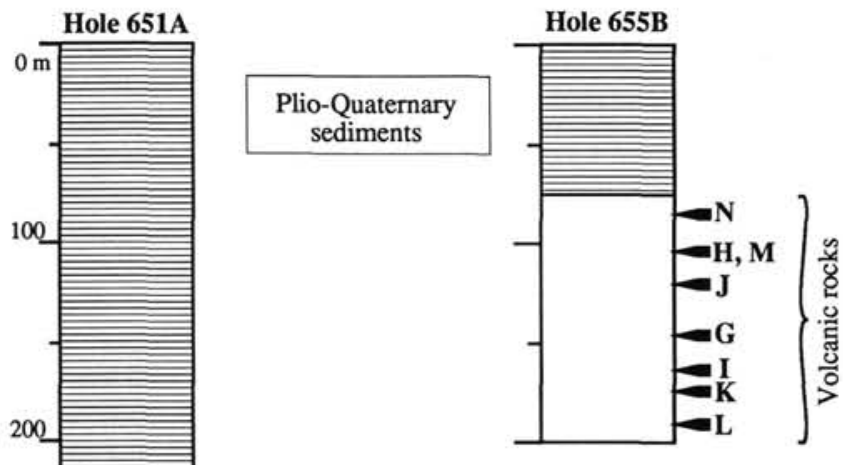

Hole Core Depth

A: 651 A 047R $01087-089$

B: $651 \mathrm{~A} 044 \mathrm{R} 02$ 146-148

C: $651 \mathrm{~A}$ 053R $02110-111$

D: $651 \mathrm{~A} 044 \mathrm{R} 01$ 132-134

E: $651 \mathrm{~A}$ 044R $02111-114$

F: $651 \mathrm{~A}$ 044R 02 143-145

G: $655 \mathrm{~B} 007 \mathrm{R} 03057-059$

H: $655 \mathrm{~B}$ 003R $01113-115$

I: $655 \mathrm{~B} 009 \mathrm{R} 03012-015$

$\mathrm{J}: \quad 655 \mathrm{~B} 005 \mathrm{R} 01026-028$

K: 655 B 010R 03 029-034

L: 655B 012R $03007-009$

M: $655 \mathrm{~B}$ 003R $04008-012$

N: $655 B$ 001R $02113-117$

Figure 2. Stratigraphic sections of igneous basement penetrated at ODP Leg 107 Holes 651A and 655B, with respective position of studied samples.

sample may come from a sill injected in the lowermost part of unit 1 , unless it belongs to the top of the doleritic unit 2 .

Modal composition appears to be relatively constant. Plagioclase is the most abundant mineral phase. Olivine, when present, is the liquidus phase. It is noteworthy that clinopyroxene phenocrysts also occur. Hydrothermal alteration effects are present in all samples, represented mainly by carbonates, chlorites, and a nearly generalized serpentinization of olivine phenocrysts.

\section{Olivine}

Because of serpentinization in Hole 651A, only Hole 655B samples can be analyzed for olivine (Table 2). Fo-content ranges from 81 to 87 (mole $\%$ ) with maximum Fo-content continuously changing from 87 to 85 , from the bottom toward the top of the volcanic pile (Fig. 3). $\mathrm{CaO}$ values of 0.2 to $0.4 \mathrm{wt} \%$ are similar to those of olivine crystallized in $\mathrm{CaO}$-rich basalts (Watson, 1979).

\section{Clinopyroxene}

There are no major differences between Hole 651A and Hole 655B clinopyroxenes (Table 3 ). In the pyroxene quadrilateral (Fig. 4), compositions of the clinopyroxene phenocrysts plot in the augite and salite fields. Two limited trends occur. The first one, toward the Fs-Wo side, is defined by some cores and rims of phenocrysts. It shows the normal path of the low pressure basaltic crystallization. The second one, toward the En-Fs side, is mainly defined by clinopyroxenes from sample G, a pillow rim, and can be interpreted as a "quench" effect (Gamble and Taylor, 1980).

When clinopyroxenes are plotted on an aluminum vs. titanium diagram (Fig. 5), a fairly linear trend is near an $\mathrm{Al} / \mathrm{Ti}$ ratio 5.5. This could indicate a similar crystallization pressure for all lavas; scattered dots (I and L samples) from Ti- and Fs-richer clinopyroxenes indicate a possible lower crystallization pressure (Boivin, 1982).

The relatively high $\mathrm{Al}$ - and $\mathrm{Ti}$-contents are quite similar to those found in alkali-basalts, as illustrated by the discrimination diagram $\mathrm{Ti} / \mathrm{Ca}+\mathrm{Na}$ (Fig. 6; Letterier et al., 1982), in which most clinopyroxenes plot in the alkaline field.

\section{Plagioclase}

Most of the analyzed phenocrysts are in the range $\mathrm{An}_{73}$ (wt \% , usually cores) to $\mathrm{An}_{60}$ (usually rims, Table 4). Generally, zoning is compatible with normal fractional crystallization. Sodic plagioclase (oligoclase) is found in completely crystallized dolerite (D-651A). An important feature distinguishes 651A and 655B samples: for the same An-content, the K-content in plagioclase is significantly higher in rocks from Hole 651A (Fig. 7). Because plagioclase phenocrysts are only slightly altered, this feature indicates that primary melts of the basalts from Hole 651A were more potassic than those from Hole 655B.

\section{Biotite}

Biotite occurs only in the doleritic sample (D). It is one of the last phases to crystallize as evidenced by its interstitial posi-

Table 1. Summary of petrographic characteristics of basalts from Holes 651A and 655B.

\begin{tabular}{|c|c|c|c|c|c|c|}
\hline Samples & Textures & Phenocrysts & Microlites & Groundmass & Alteration & Remarks \\
\hline \multicolumn{7}{|l|}{ Hole 651A } \\
\hline A & microlitic with phenocrysts & Ol, Pl, Cpx & Pl, Cpx, TiMt & Cpx, Ore: quench & Chl, Serp, leucoxene & from lava flow? \\
\hline $\mathbf{B}$ & microlitic with phenocrysts & $\mathrm{Ol}, \mathrm{Pl}, \mathrm{Cpx}$ & $\mathrm{Pl}, \mathrm{Cpx}, \mathrm{TiMt}$ & Cpx, Ore: quench & Chl, Serp, leucoxene & from pillow \\
\hline C & microlitic with phenocrysts & $\mathrm{Ol}, \mathrm{Pl}, \mathrm{Cpx}$ & Ol, Pl, Cpx, TiMt & devritified glass, quench & Chl, Alk-Feldp, Serp & pillow rim \\
\hline D & doleritic & $\mathrm{Cpx}, \mathrm{Pl}$ & $\mathrm{Cpx}, \mathrm{Pl}, \mathrm{Ilm}, \mathrm{Bi}$ & & Chl, Amph, & from sill \\
\hline $\mathbf{E}$ & microlitic with phenocrysts & $\mathrm{Pl}, \mathrm{Cpx}$ & Pl, Cpx, TiMt & Cpx, Ore: quench & Chl, Serp, Cc, leucoxene & from lava flow? \\
\hline \multicolumn{7}{|c|}{ Hole 655B } \\
\hline G & glassy with phenocrysts & Ol, PI, Cpx & & devritified glass, quench & Cc, palagonite (traces) & pillow rim \\
\hline I & microlitic with phenocrysts & Ol, PI, Cpx & Pl, Cpx, TiMt & Cpx, Ore: quench & Chl, Serp, Cc, leucx, clay & from lava flow? \\
\hline $\mathbf{J}$ & glassy with phenocrysts & Ol, Pl, Cpx & & Cpx, Pl, Ore: quench & $\mathrm{Cc}$ & pillow rim \\
\hline $\mathbf{K}$ & microlitic with phenocrysts & Ol, PI, Cpx & Pl, Cpx, TiMt & Cpx, Ore: quench & Chl, Serp, Cc, leucoxene & from lava flow? \\
\hline $\mathbf{L}$ & microlitic with phenocrysts & Ol, Pl, Cpx & $\mathrm{Pl}, \mathrm{Cpx}$, TiMt & Cpx, Ore: quench & Serp, Cc & from lava flow? \\
\hline $\mathbf{N}$ & microlitic with phenocrysts & $\mathrm{Ol}, \mathrm{Pl}, \mathrm{Cpx}$ & Pl, Cpx, TiMt & Cpx, Ore: quench & Chl, Serp & from lava flow? \\
\hline
\end{tabular}


Table 2. Representative analyses of olivines from Hole 655B.

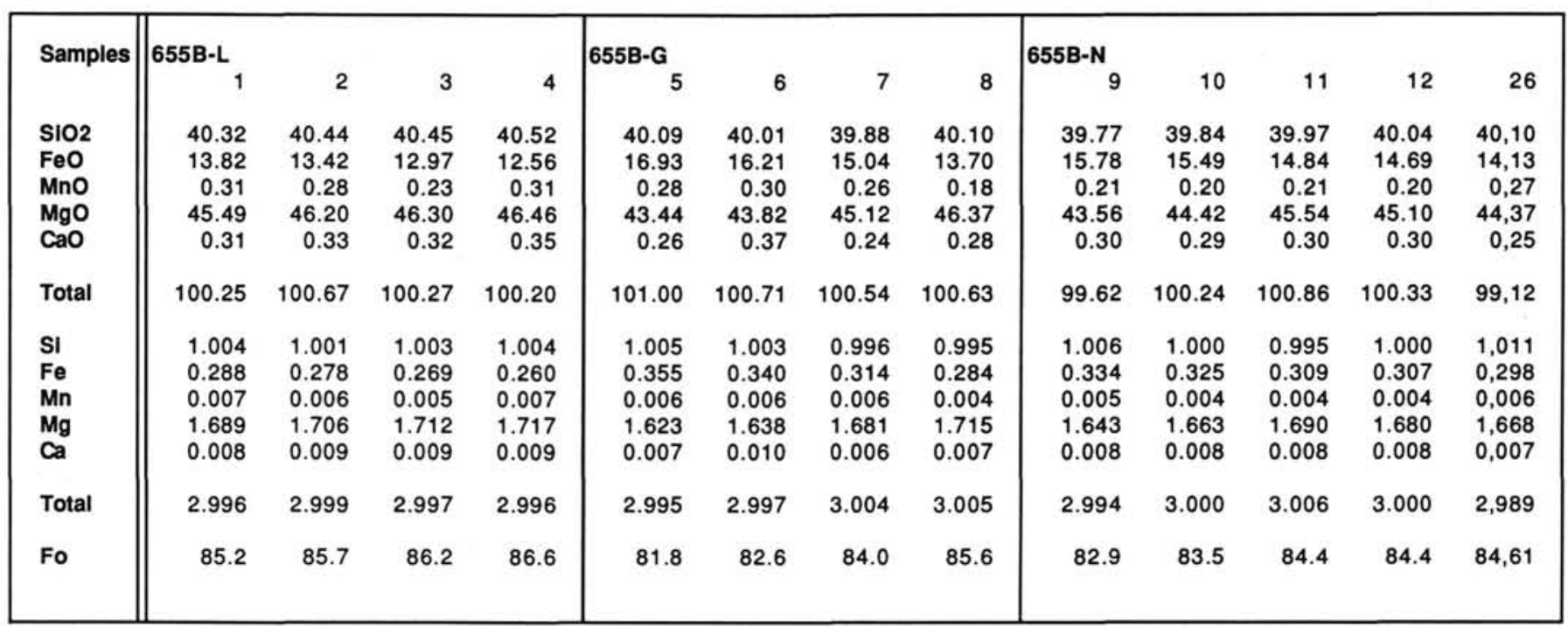

tion. In spite of limited chloritic transformation, it is magmatic. As plagioclases in which $\mathrm{K}$ content is high, this mineral indicates a greater $\mathrm{K}_{2} \mathrm{O}$ content in the melt. $\mathrm{Mg}$-value ranges from $55 \%$ to $71 \%$, close to the biotite-phlogopite divide (Table 5).

\section{Opaque Oxides}

Two types of opaque oxides were analyzed in C and D samples (Hole 651A). The first type is a chromitic spinel (Table 6, col. 1-2) found as small phenocrysts associated with Ti-magnetite. Because of alteration, no valuable analysis of this phase was possible. The second type is ilmenite (Table 6, col. 3-5) found in the doleritic sample. It has homogeneous compositions throughout the rock.

\section{MAIN GEOCHEMICAL CHARACTERISTICS}

\section{Major Elements and Loss on Ignition}

Nine whole-rock analyses are presented in Table 7. Although all of them are basaltic in composition, these rocks have high loss on ignition (LOI) values, between 3.06 and $6.59 \mathrm{wt} \%$. Only a limited part of LOI content may be primary dissolved volatiles, as a consequence of high volatile content in the source regions due to dehydration of the subducted plate adjacent to the back-arc-basin. Similar interpretations have been proposed on other back-arc-basalts (BAB) (Gill, 1976; Marsh et al., 1980; Tarney et al., 1981; Fryer et al., 1982). Therefore, the measured LOI contents mainly result from seawater alteration accordingly to abundance of secondary phases. It is not easy to appraise to what extent basalt seawater interaction may modify major-element chemistry. The chemical effects of alteration depend on several factors such as temperature, water-rock ratio, and rock crystallinity (Seyfried and Bischoff, 1979; Seyfried and Mottl, 1982), and the final budget cannot be evaluated from the limited set of available data. Note that at Hole $655 \mathrm{~B}$, the concentrations of $\mathrm{Na}_{2} \mathrm{O}$ and $\mathrm{K}_{2} \mathrm{O}$ remain constant, whatever LOI contents, and therefore do not seem to have been greatly modified by alteration.

\section{Magmatic Affinity}

The high LOI values make difficult the characterization of magmatic affinity using major-element chemistry. At first sight, one could conclude in favor of an alkaline character, considering normative compositions of the rocks include nepheline, ex- cept $\mathrm{D}$ and $\mathrm{E}$ which are olivine and hypersthene normative (Table 7). But it is obvious that alteration involves undersaturation, particularly if the groundmass contains abundant devitrified glass (see samples $\mathrm{C}$ and $\mathrm{G}$ with $12.88 \%$ and $10.52 \%$ of normative nepheline). On the other hand, the apparent alkaline affinity indicated by the $\mathrm{Na}_{2} \mathrm{O}+\mathrm{K}_{2} \mathrm{O}$ vs. $\mathrm{SiO}_{2}$ diagram (Fig. 8) may result from an alkali enrichment during early processes such as transfer by a fluid phase through the dehydration of the adjacent subducted plate (Tatsumi et al., 1986).

Therefore, a more reliable characterization is required using the less mobile major elements $\mathrm{Ti}$ and $\mathrm{P}$ whose relatively low contents (Table 7) emphasize a tholeiitic character, as shown in the diagrams $\mathrm{P}_{2} \mathrm{O}_{5}$ vs. $\mathrm{Zr}$ (Fig. 9), and $\mathrm{TiO}_{2}$ vs. Y/Nb (Fig. 10). $\mathrm{Mg}$-values extend from 0.70 to 0.57 and indicate that the drilled basalts have suffered a moderate fractionation, characterized by a slighter Fe-enriched trend on the AFM diagram compared to MORB (Fig. 11), as is generally the case for back-arc-basalts (BAB) (Fig. 11).

\section{Comparison with $N-M O R B$ and $B A B$}

In order to better evaluate their chemistry, basalts from Holes $651 \mathrm{~A}$ and $655 \mathrm{~B}$ are compared with both N-type MORB (MORB from normal ridge segments) and BAB using major-element oxide variations vs. Mg-value (Fig. 12). A reference set of $\mathrm{N}$-MORB is made up by more than 150 analyses of basalts drilled in the Atlantic ocean between $33^{\circ} \mathrm{N}$ and $56^{\circ} \mathrm{N}$ latitudes during DSDP Legs $11,37,49,80$, and 81 . This set of data is representative of oceanic layer 2 nearest to the Mediterranean basin. The reference BAB set consists of 20 analyses selected from the Pacific basins (Mariana Trough, Lau, Parece Vela, West Philippines, Bransfield Strait) and East Scotia Sea and West Scotia Sea. If we except $\mathrm{Na}_{2} \mathrm{O}$ and partly $\mathrm{K}_{2} \mathrm{O}, \mathrm{N}-\mathrm{MORB}$ and $\mathrm{BAB}$ reference sets have similar major-element concentrations. The majority of Leg 107 basalts fall within the overlapping zone of the two fields. Only on the $\mathrm{Na}_{2} \mathrm{O}$ plot the two fields are quite distinct, and Leg 107 basalts clearly show a BAB rather than MORB affinity. Basalts from the upper unit 1 of the Hole 651A (samples D and E) deviate from the BAB field by their higher $\mathrm{K}_{2} \mathrm{O}$ and lower $\mathrm{CaO}$ contents. The opposite behavior of the two elements could be a consequence of low-temperature seawater alteration (Seyfried and Bischoff, 1979). But at least a part of the greater $\mathrm{K}_{2} \mathrm{O}$ content is a primary magmatic feature, as already inferred from compositions of plagioclases and presence of biotite. 

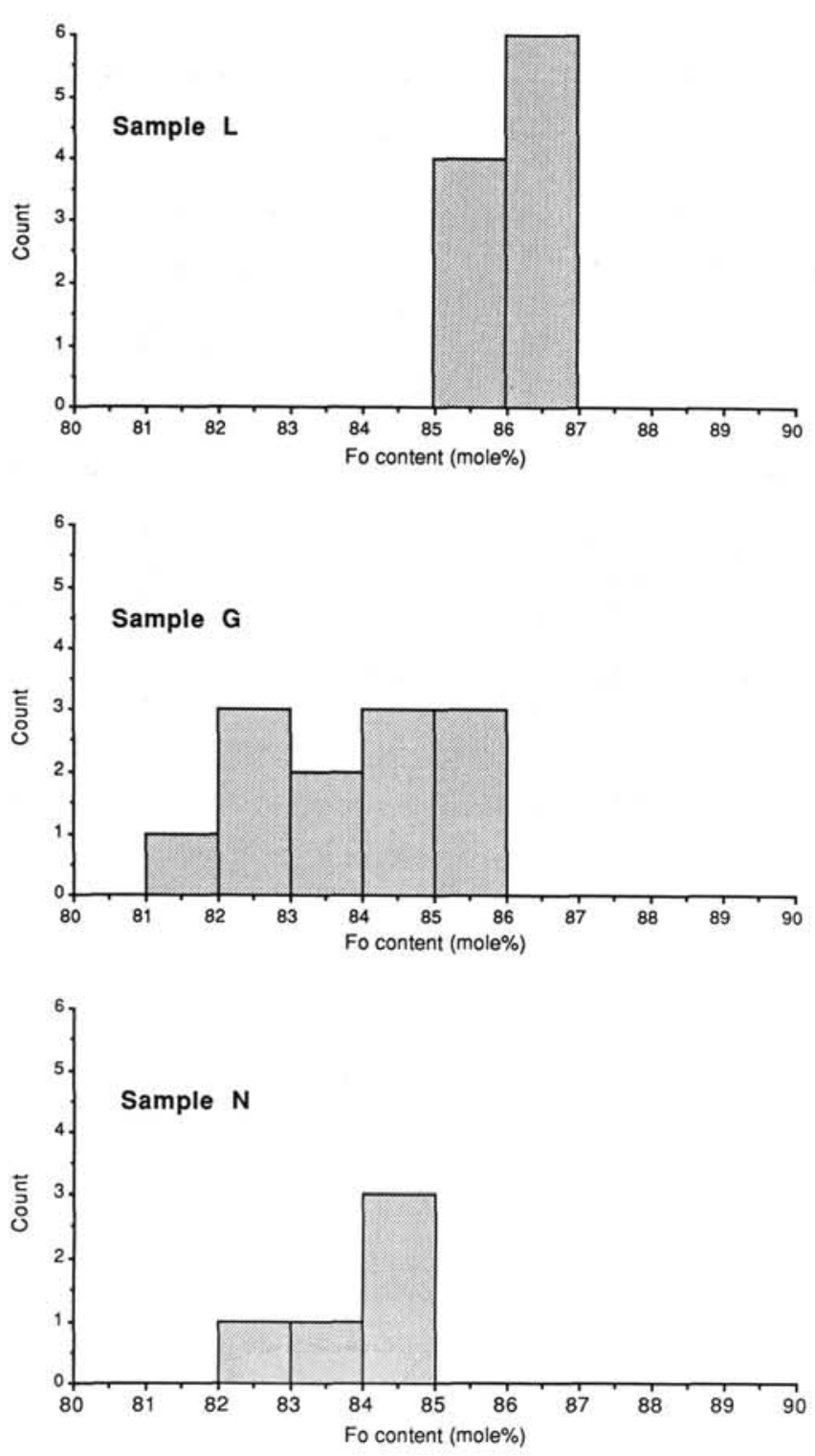

Figure 3. Histogram of molecular Fo content of olivine, from ODP Leg 107, Hole 655B (samples G, L, N).

\section{Intersite Relationships Within Vavilov Basin}

Basalts from Hole 655B form a relatively homogeneous volcanic pile, with little chemical change throughout the sequence. They closely resemble high- $\mathrm{TiO}_{2}$ basalts of Leg 42, Site 373 (Barberi et al., 1978), from the eastern portion of the basin. On the contrary, the limited data for basalts from Hole 651A appear more heterogeneous in chemistry with greater variations of $\mathrm{Na}_{2} \mathrm{O}, \mathrm{K}_{2} \mathrm{O}, \mathrm{CaO}, \mathrm{MgO}$ than in Hole 655B. Sample $\mathrm{C}$ from unit 3 resembles Hole 655B basalts except in its higher $\mathrm{Na}_{2} \mathrm{O}$ content, whereas samples $\mathrm{D}$ and $\mathrm{E}$ from upper unit 1 contain more $\mathrm{K}_{2} \mathrm{O}$ and $\mathrm{MgO}$, and less $\mathrm{CaO}$. More recent basalts sampled at the base of Vavilov seamount (Robin et al., 1987) differ from most of the surrounding seafloor rocks by their higher abundances of $\mathrm{K}_{2} \mathrm{O}, \mathrm{TiO}_{2}$, and lower LOI values. On the basis of these elements, they often plot outside the fields of both $\mathrm{N}$ MORB and BAB (Fig. 12), and have a mildly alkaline affinity (Fig. 10), suggesting Vavilov is independent of the oceanic crust which supports it, as already stressed by Robin et al. (1987).

These intersite comparisons reveal chemical similarities (Holes $655 \mathrm{~B}$ and 373 ), but also time-related compositional variations.
The oldest volcanics were recorded in Hole 373 which provided high-Ti basalts in Cores 5, 6, 11, and 12 interlayered with low- Ti basalts (Dietrich et al., 1977). Using the available ages obtained on these two basaltic groups and their stratigraphic relationships (Dietrich et al., 1977; Barberi et al., 1978; Kreuser et al., 1978), one can conclude that the outpouring of the high-Ti basalts at Site 373 may have occur during the interval 7.5 m.y./ $<3.6$ m.y. Eruption of Hole 655B basalts, which occupy a symmetric position with respect to the basin center, occurred around $4.3 \mathrm{~m}$.y. (Féraud, this volume). Therefore, the basalts from these two sites, similar in composition (high-Ti group), may be partly contemporaneous. Basalts from Hole 651A are younger with an inferred age of 3/2.6 m.y. (Féraud, this volume), and those from Vavilov seamount are much more recent, i.e., less than 0.5 m.y. (Robin et al., 1987).

\section{Trace Elements}

Trace elements compositions are presented in Table 8 .

\section{Magmatic Affinity and Tectonic Setting}

Because major-element characteristics are somewhat conflicting, it is important to consider immobile trace elements such as $\mathrm{Zr}, \mathrm{Nb}$, and $\mathrm{Y}$. For example, in a magmatic discrimination diagram based upon $\mathrm{Y} / \mathrm{Nb}$ ratio (Floyd and Winchester, 1975; Pearce, 1982), the lavas from both Holes 651A and 655B fall within the field of tholeiites and are aligned according a typical tholeiitic trend (Fig. 10). This supports the tendency expressed by the less mobile major elements, $\mathrm{Ti}$ and $\mathrm{P}$. The same behavior seems to be verified for the Pacific BAB although the available data are still scarce. These diagrams confirm the alkaline tendency of Vavilov seamount basalts.

When they are plotted on tectonomagmatic diagrams involving Zr, Ti, and Y (Pearce and Cann, 1973; Pearce and Norry, 1979), Leg 107 volcanics are restricted within the field of all MORB (for example, Fig. 13). They do not show arc affinity on the basis of these elements, whereas Pacific BAB overlap several tectonomagmatic fields. They also have a MORB-like character in $\mathrm{Ti}$ vs. V plot (Shervais, 1982) and Ti vs. Cr plots (Pearce, 1975). However, none of these diagrams were conceived to distinguish MORB and BAB. Compared to Leg 107 basalts, Vavilov seamount lavas have some within-plate-basalt tendency. Although reliability of these diagrams is sometimes debatable (Bertrand, 1987), their interpretation is easier for oceanic rocks. Leg 107 lavas are clearly associated with an extension environment in good agreement with geophysical data, but these trace elements cannot specify more exactly their tectonomagmatic environment.

\section{Geochemical Fingerprint Using Hygromagmaphile Elements}

Previous sections have shown that Leg 107 basalts are close to N-MORB on the basis of immobile elements such as Ti, P, $\mathrm{Zr}$, and $\mathrm{Y}$ but different by their higher alkali content. Therefore, a more detailed trace-element investigation is required to evaluate to what extent they resemble MORB or BAB (if any difference exists), and if the influence of the adjacent subduction on their geochemistry may be perceptible. For this purpose, we present multi-element spidergrams including rare-earth elements and other trace elements that are more or less hygromagmaphile. All data are normalized to N-MORB (average composition after Sun et al., 1979) in order to better visualize comparisons with typical "normal" oceanic crust.

Figure 14 represents spidergrams of Hole $655 \mathrm{~B}$ basalts. Firstly, they confirm the homogeneity of the basalts. Secondly, it clearly appears that these basalts are different from N-MORB, that is, from "normal" oceanic crust characteristic of the neighboring Atlantic ocean outside plume or hot spots. Their patterns are very regular without pronounced anomalies. They are strictly identical to N-MORB along the segment Gd-Lu, but they show 
Table 3. Representative analyses of clinopyroxenes from Holes 651A and 655B.

\begin{tabular}{|c|c|c|c|c|c|c|c|c|c|c|c|c|c|c|}
\hline Samples & $\begin{array}{r}\text { 651A-C } \\
1 \\
\mathrm{C}\end{array}$ & $\begin{array}{l}2 \\
e\end{array}$ & $\begin{array}{r}\text { 651A-D } \\
3 \\
C\end{array}$ & $\begin{array}{l}4 \\
\text { e }\end{array}$ & $\begin{array}{r}651 A-E \\
5\end{array}$ & 6 & $\begin{array}{r}655 B-G \\
7 \\
C\end{array}$ & $\begin{array}{l}8 \\
e\end{array}$ & $\begin{array}{r}655 \mathrm{~B}-1 \\
9 \\
\mathrm{C}\end{array}$ & $\begin{array}{r}10 \\
\mathrm{e}\end{array}$ & $\begin{array}{r}655 B-L \\
11\end{array}$ & 12 & $\begin{array}{r}655 \mathrm{~B}-\mathrm{N} \\
13 \\
\mathrm{C}\end{array}$ & $\begin{array}{r}14 \\
e\end{array}$ \\
\hline $\mathrm{SIO2}$ & 47.92 & 47.09 & 47.99 & 48.39 & 47.66 & 48.65 & 51.70 & 51.07 & 51.03 & 53.04 & 48.82 & 45.55 & 47.89 & 47.28 \\
\hline $\mathrm{TIO2}$ & 2.09 & 2.32 & 1.73 & 1.39 & 2.24 & 1.80 & 1.00 & 1.07 & 0.97 & 0.50 & 1.69 & 3.83 & 2.03 & 2.54 \\
\hline$A \mid 203$ & 7.17 & 5.55 & 6.32 & 4.96 & 6.85 & 5.78 & 3.61 & 3.92 & 3.72 & 2.03 & 6.85 & 5.92 & 6.90 & 7.05 \\
\hline $\mathrm{Cr} 2 \mathrm{O} 3$ & 0.05 & 0.36 & 0.41 & 0.12 & 0.04 & 0.13 & 0.32 & 0.75 & 0.01 & 0.08 & 0.04 & 0.22 & 0.18 & 0.11 \\
\hline $\mathrm{FeO}$ & 6.83 & 9.31 & 6.33 & 8.97 & 9.34 & 7.35 & 7.02 & 6.62 & 7.58 & 7.61 & 7.82 & 13.52 & 8.04 & 8.32 \\
\hline MnO & 0.15 & 0.20 & 0.13 & 0.26 & 0.21 & 0.25 & 0.16 & 0.02 & 0.16 & 0.31 & 0.27 & 0.29 & 0.15 & 0.23 \\
\hline $\mathrm{MgO}$ & 13.31 & 12.19 & 14.19 & 13.66 & 13.06 & 14.56 & 15.92 & 16.49 & 15.11 & 16.62 & 14.47 & 9.58 & 13.40 & 12.82 \\
\hline $\mathrm{CaO}$ & 22.59 & 21.38 & 21.49 & 20.72 & 20.25 & 20.26 & 21.37 & 20.71 & 21.81 & 20.27 & 18.77 & 20.95 & 21.30 & 21.40 \\
\hline $\mathrm{Na2O}$ & 0.31 & 0.39 & 0.28 & 0.33 & 0.51 & 0.32 & 0.35 & 0.37 & 0.25 & 0.25 & 0.44 & 0.61 & 0.46 & 0.48 \\
\hline Total & 100.42 & 98.79 & 98.87 & 98.80 & 100.16 & 99.10 & 101.45 & 101.02 & 100.64 & 100.71 & 99.17 & 100.47 & 100.35 & 100.23 \\
\hline SI & 1.767 & 1.786 & 1.791 & 1.821 & 1.772 & 1.814 & 1.875 & 1.855 & 1.873 & 1.938 & 1.817 & 1.735 & 1.770 & 1.756 \\
\hline$\pi$ & 0.058 & 0.066 & 0.049 & 0.039 & 0.063 & 0.050 & 0.027 & 0.029 & 0.027 & 0.014 & 0.047 & 0.110 & 0.056 & 0.071 \\
\hline Al & 0.312 & 0.248 & 0.278 & 0.220 & 0.300 & 0.254 & 0.154 & 0.168 & 0.161 & 0.087 & 0.300 & 0.266 & 0.301 & 0.309 \\
\hline $\mathrm{Fe} 3+$ & 0.058 & 0.065 & 0.051 & 0.079 & 0.066 & 0.037 & 0.055 & 0.068 & 0.057 & 0.024 & 0.002 & 0.084 & 0.074 & 0.069 \\
\hline Cr & 0.001 & 0.011 & 0.012 & 0.004 & 0.001 & 0.004 & 0.009 & 0.022 & 0.000 & 0.002 & 0.001 & 0.007 & 0.005 & 0.003 \\
\hline $\mathrm{Fe} 2+$ & 0.152 & 0.231 & 0.146 & 0.203 & 0.224 & 0.192 & 0.157 & 0.133 & 0.175 & 0.208 & 0.241 & 0.347 & 0.175 & 0.190 \\
\hline Mn & 0.005 & 0.006 & 0.004 & 0.008 & 0.007 & 0.008 & 0.005 & 0.001 & 0.005 & 0.010 & 0.009 & 0.009 & 0.005 & 0.007 \\
\hline $\mathrm{Mg}$ & 0.732 & 0.689 & 0.789 & 0.766 & 0.724 & 0.809 & 0.861 & 0.893 & 0.827 & 0.905 & 0.803 & 0.544 & 0.738 & 0.710 \\
\hline $\mathrm{Ca}$ & 0.893 & 0.869 & 0.859 & 0.835 & 0.807 & 0.809 & 0.831 & 0.806 & 0.858 & 0.794 & 0.748 & 0.855 & 0.843 & 0.852 \\
\hline $\mathrm{Na}$ & 0.022 & 0.029 & 0.020 & 0.024 & 0.037 & 0.023 & 0.025 & 0.026 & 0.018 & 0.018 & 0.032 & 0.045 & 0.033 & 0.035 \\
\hline Total & 4.000 & 4.000 & 4.000 & 4.000 & 4.000 & 4.000 & 4.000 & 4.000 & 4.000 & 4.000 & 4.000 & 4.000 & 4.000 & 4.000 \\
\hline En & 39.8 & 37.1 & 42.7 & 40.5 & 39.6 & 43.6 & 45.1 & 47.0 & 43.0 & 46.7 & 44.5 & 29.6 & 40.2 & 38.9 \\
\hline Fs & 11.7 & 16.2 & 10.9 & 15.3 & 16.2 & 12.8 & 11.4 & 10.6 & 12.4 & 12.5 & 14.0 & 23.9 & 13.8 & 14.5 \\
\hline Wo & 48.5 & 46.7 & 46.4 & 44.1 & 44.1 & 43.6 & 43.5 & 42.4 & 44.6 & 40.9 & 41.5 & 46.5 & 46.0 & 46.6 \\
\hline MG & 77.3 & 69.6 & 79.7 & 72.5 & 70.9 & 77.4 & 79.8 & 81.6 & 77.7 & 78.9 & 76.1 & 55.3 & 74.5 & 72.8 \\
\hline
\end{tabular}

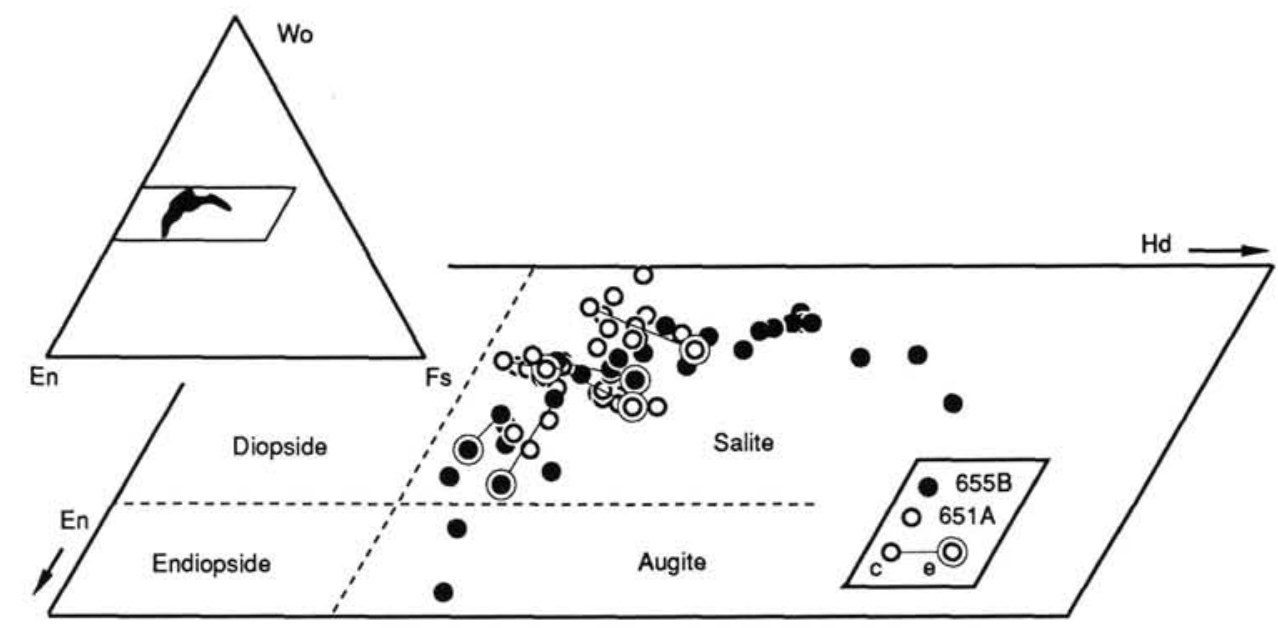

Figure 4. Clinopyroxene compositions from ODP Holes $651 \mathrm{~A}$ and $655 \mathrm{~B}$, plotted in the pyroxene quadrilateral.

a gradual enrichment from Gd toward Rb, i.e., in most incompatible elements (enrichment factor of $2 \times$ for $\mathrm{La}, 4 \times$ for $\mathrm{Rb}$ ). These rocks are enriched tholeiites and present similarities with E-type MORB (enriched MORB). It is to be noted that K (and $\mathrm{Rb}$ ) is well integrated within the general pattern, conformably to less mobile elements, supporting $\mathrm{K}$ contents as primary rather than secondary. The spidergrams can be exactly superimposed to those of the high-Ti group from Site 373, suggesting that the lavas of the two sites may have been generated from a similar mantle source, and by similar magmatic processes. Comparable spidergrams from the reference BAB samples exist for East Scotia Sea (Saunders and Tarney, 1979), or in part Bransfield Strait, except Nb-anomaly, (Weaver et al., 1979). Unfortunately, com- parisons are limited by the number of data available in the literature for making a full spidergram.

Figure 15 presents spidergrams for lavas from Hole $651 \mathrm{~A}$, illustrating much more variable patterns. The observed variations reflect time-related magmatic evolution within the hole from Unit 3 toward Unit 1. Sample C (Unit 3) is similar to Hole 655B basalts, although heavy-rare-earth-elements (HREE) appear a little more fractionated. On the other hand, samples D and E (Unit 1) are considerably different from Hole 655B basalts. They are identical to lower Unit 3 basalt along the segment Eu$\mathrm{Lu}$, but they display a highly enriched pattern for light REE (LREE) and other large ion lithophile elements (LILE), with a positive slope from Eu to Rb. Enrichment factors, compared to 


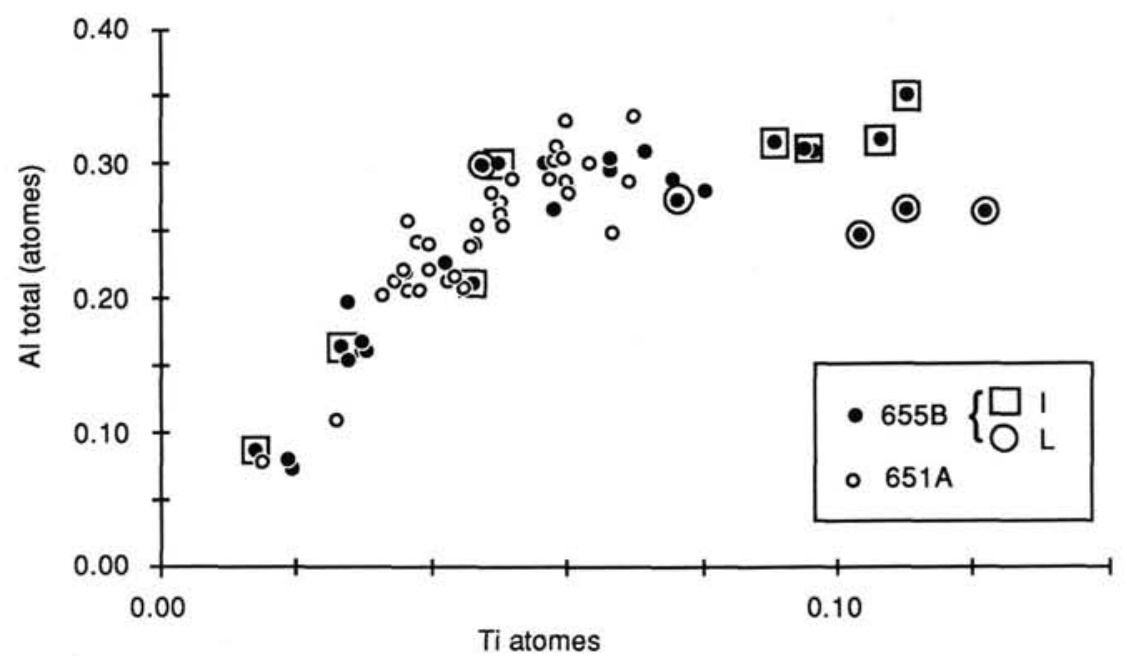

Figure 5. Al total vs. Ti plot for clinopyroxenes from ODP Holes $651 \mathrm{~A}$ and 655B.

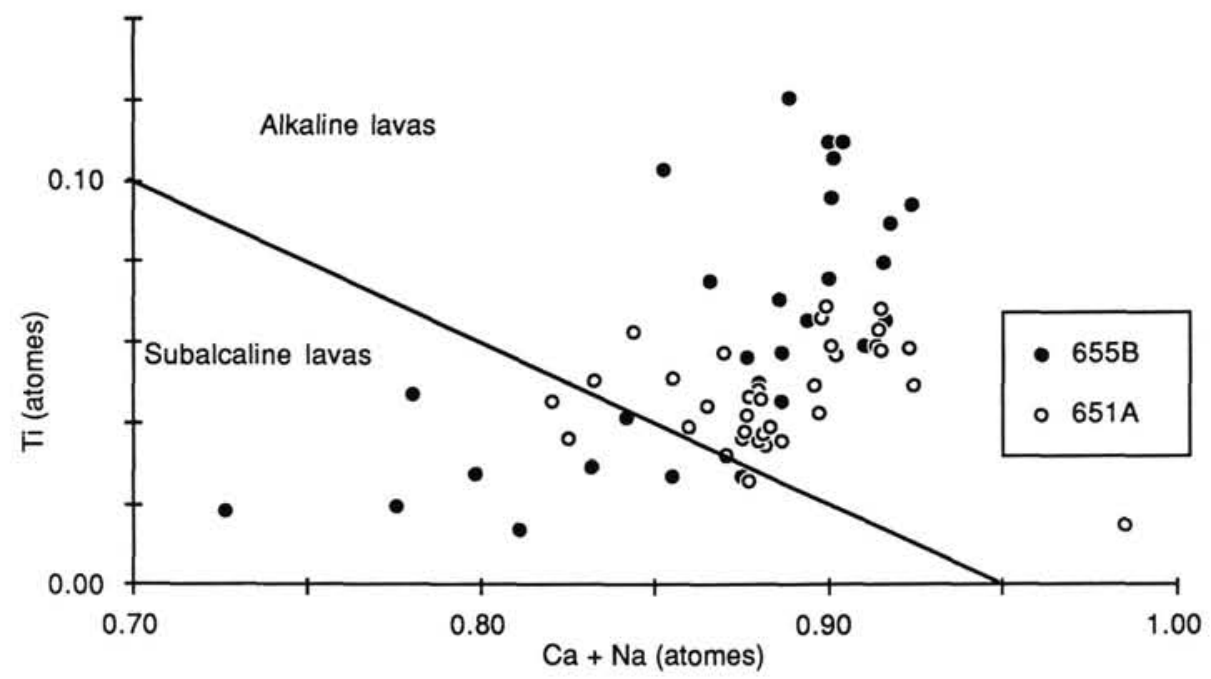

Figure 6. Clinopyroxenes from ODP Holes $651 \mathrm{~A}$ and $655 \mathrm{~B}$ in the discrimination diagram Ti vs. Ca $+\mathrm{Na}$ (after Leterrier et al., 1982).

$\mathrm{N}-\mathrm{MORB}$, is about 5 for $\mathrm{La}$ and from 8 to 35 for Rb. A dominant feature of these spidergrams (Upper unit) is the strong negative $\mathrm{Nb}$-anomaly, whereas other high-field-strength-elements (HFSE) such as $\mathrm{Zr}, \mathrm{Ti}$, and $\mathrm{Y}$ accord with the general pattern.

Another characteristic of these spidergrams is how completely different they are from those of both N-type or E-type MORB, along the segment Gd-Rb; however, an interesting comparison is with calc-alkaline lavas. A striking feature is the strong similarity of pattern shape between the upper basalts of Hole 651A and andesitic lavas from Stromboli (Dupuy et al., 1981; Luais, 1986) (Fig. 15), in the Eolian Island arc adjacent to the Tyrrhenian Sea, although these latter are more HREE fractionated and display a negative $\mathrm{Ti}$ anomaly. Therefore, upper basalts of Hole 651A, although not identical to orogenic lavas, present a calc-alkaline tendency on the basis of their strong enrichment in LILE together with a Nb depletion. It is to be noted that in other back-arc environments (for example, in Mariana Trough, Wood et al., 1982; Bransfield Strait, Weaver et al., 1979; East Scotia Sea, Saunders and Tarney, 1979), some basalts with more or less LILE enriched (respective to N-MORB) patterns, also display a negative $\mathrm{Nb}$ anomaly (Fig. 16).
In order to have a comprehensive view of the geochemistry of Vavilov Basin basalts, Figure 15 also presents two patterns from Vavilov seamount, which differ from seafloor lavas of Leg 107 and 42 , in having a very regular and positive slope from less to more hygromagmaphile elements, and a nearly positive $\mathrm{Nb}$ anomaly. Such features make these lavas close to oceanic-islandbasalts (OIB), as described in Robin et al. (1987). This is in good accordance with the alkaline and within plate tendencies deduced from immobile element geochemistry.

\section{DISCUSSION AND IMPLICATION FOR EVOLUTION OF THE TYRRHENIAN BASIN}

Over the last decade, many investigations have been performed on back-arc basins, providing an increased amount of geochemical data about basalts erupted at these spreading centers (although knowledge of them is still limited with respect to wide oceans). Back-arc basalts display a broad range of chemical compositions, from N-MORB-like tholeiitic types (Ridley et al., 1974; Wood et al., 1981; Tarney et al., 1981; Marsh et al., 1980; Sharaskin et al., 1981), to basaltic types with island-arc or calc-alkaline affinity, sometimes within the same basin (Weaver 
Table 4. Representative analyses of plagioclases from Holes 651A and 655B.

\begin{tabular}{|c|c|c|c|c|c|c|c|c|c|c|c|c|c|c|}
\hline Samples & $651 \mathrm{~A}-\mathrm{C}_{1}$ & 2 & $\begin{array}{r}\text { 651A-D } \\
3 \\
\mathrm{C}\end{array}$ & $\begin{array}{l}4 \\
\text { e }\end{array}$ & $\begin{array}{r}651 \mathrm{~A}-\mathrm{E} \\
5 \\
\mathrm{C}\end{array}$ & $\begin{array}{l}6 \\
\text { e }\end{array}$ & $\begin{array}{r}655 \mathrm{~B}-1 \\
\\
\\
\\
\\
\\
\mathrm{C}\end{array}$ & $\begin{array}{l}8 \\
\text { e }\end{array}$ & $\begin{array}{r}655 B-L \\
9 \\
C\end{array}$ & $\begin{array}{r}10 \\
e\end{array}$ & $\begin{array}{r}655 B-G \\
11 \\
C\end{array}$ & $\begin{array}{r}12 \\
e\end{array}$ & $\begin{array}{r}655 \mathrm{~B}-\mathrm{N} \\
13 \\
\mathrm{C}\end{array}$ & $\begin{array}{r}14 \\
b\end{array}$ \\
\hline $\mathrm{SIO}_{2}$ & 50.68 & 50.95 & 56.50 & 59.85 & 51.42 & 50.46 & 50.29 & 51.78 & 53.23 & 51.79 & 52.66 & 51.23 & 51.55 & 50.67 \\
\hline TIO2 & 0.05 & 0.10 & 0.05 & 0.01 & 0.02 & 0.03 & 0.05 & 0.04 & 0.04 & 0.15 & 0.02 & 0.14 & 0.04 & 0.07 \\
\hline Al2O3 & 30.56 & 30.47 & 27.71 & 25.01 & 31.02 & 31.32 & 31.87 & 30.52 & 29.80 & 30.97 & 29.76 & 30.72 & 30.97 & 31.41 \\
\hline $\mathrm{FeO}$ & 0.61 & 0.54 & 0.38 & 0.42 & 0.53 & 0.63 & 0.22 & 0.44 & 0.58 & 0.52 & 0.50 & 0.52 & 0.38 & 0.47 \\
\hline $\mathrm{MgO}$ & 0.23 & 0.25 & 0.04 & . & 0.14 & 0.15 & 0.19 & 0.20 & 0.17 & 0.24 & 0.19 & 0.15 & 0.19 & 0.20 \\
\hline $\mathrm{CaO}$ & 13.34 & 13.62 & 9.25 & 6.15 & 13.79 & 14.28 & 14.96 & 13.84 & 13.02 & 13.97 & 12.95 & 14.16 & 13.60 & 14.38 \\
\hline $\mathrm{Na2O}$ & 3.62 & 3.59 & 5.98 & 7.73 & 3.41 & 3.22 & 3.04 & 3.62 & 4.04 & 3.49 & 4.18 & 3.46 & 3.71 & 3.26 \\
\hline K2O & 0.16 & 0.17 & 0.26 & 0.49 & 0.12 & 0.13 & 0.06 & 0.05 & 0.07 & 0.07 & 0.03 & 0.07 & 0.06 & 0.04 \\
\hline Total & 99.25 & 99.69 & 100.17 & 99.66 & 100.45 & 100.22 & 100.68 & 100.49 & 100.95 & 101.20 & 100.29 & 100.45 & 100.50 & 100.50 \\
\hline SI & 2.329 & 2.332 & 2.537 & 2.684 & 2.331 & 2.300 & 2.280 & 2.346 & 2.395 & 2.332 & 2.386 & 2.327 & 2.334 & 2.300 \\
\hline$\pi$ & 0.002 & 0.003 & 0.002 & 0.000 & 0.001 & 0.001 & 0.002 & 0.001 & 0.001 & 0.005 & 0.001 & 0.005 & 0.001 & 0.002 \\
\hline Al & 1.655 & 1.643 & 1.467 & 1.322 & 1.658 & 1.683 & 1.703 & 1.630 & 1.580 & 1.643 & 1.589 & 1.644 & 1.653 & 1.680 \\
\hline $\mathrm{Fe}$ & 0.023 & 0.021 & 0.014 & 0.016 & 0.020 & 0.024 & 0.008 & 0.017 & 0.022 & 0.020 & 0.019 & 0.020 & 0.014 & 0.018 \\
\hline $\mathrm{Mg}$ & 0.016 & 0.017 & 0.003 & 0.000 & 0.009 & 0.010 & 0.013 & 0.014 & 0.011 & 0.016 & 0.013 & 0.010 & 0.013 & 0.014 \\
\hline $\mathrm{Ca}$ & 0.657 & 0.668 & 0.445 & 0.295 & 0.670 & 0.697 & 0.727 & 0.672 & 0.627 & 0.674 & 0.628 & 0.689 & 0.660 & 0.699 \\
\hline $\mathrm{Na}$ & 0.323 & 0.319 & 0.521 & 0.672 & 0.300 & 0.285 & 0.267 & 0.318 & 0.352 & 0.305 & 0.367 & 0.305 & 0.326 & 0.287 \\
\hline$K$ & 0.005 & 0.005 & 0.007 & 0.014 & 0.003 & 0.004 & 0.002 & 0.001 & 0.002 & 0.002 & 0.001 & 0.002 & 0.002 & 0.001 \\
\hline Total & 5.008 & 5.007 & 4.995 & 5.004 & 4.992 & 5.003 & 5.002 & 4.998 & 4.992 & 4.996 & 5.003 & 5.001 & 5.003 & 5.002 \\
\hline or & 0.5 & 0.5 & 0.8 & 1.4 & 0.4 & 0.4 & 0.2 & 0.1 & 0.2 & 0.2 & 0.1 & 0.2 & 0.2 & 0.1 \\
\hline$A b$ & 32.8 & 32.1 & 53.5 & 68.5 & 30.8 & 28.9 & 26.8 & 32.1 & 35.9 & 31.1 & 36.8 & 30.6 & 33.0 & 29.1 \\
\hline An & 66.7 & 67.4 & 45.7 & 30.1 & 68.8 & 70.7 & 73.0 & 67.8 & 63.9 & 68.7 & 63.1 & 69.2 & 66.8 & 70.8 \\
\hline
\end{tabular}

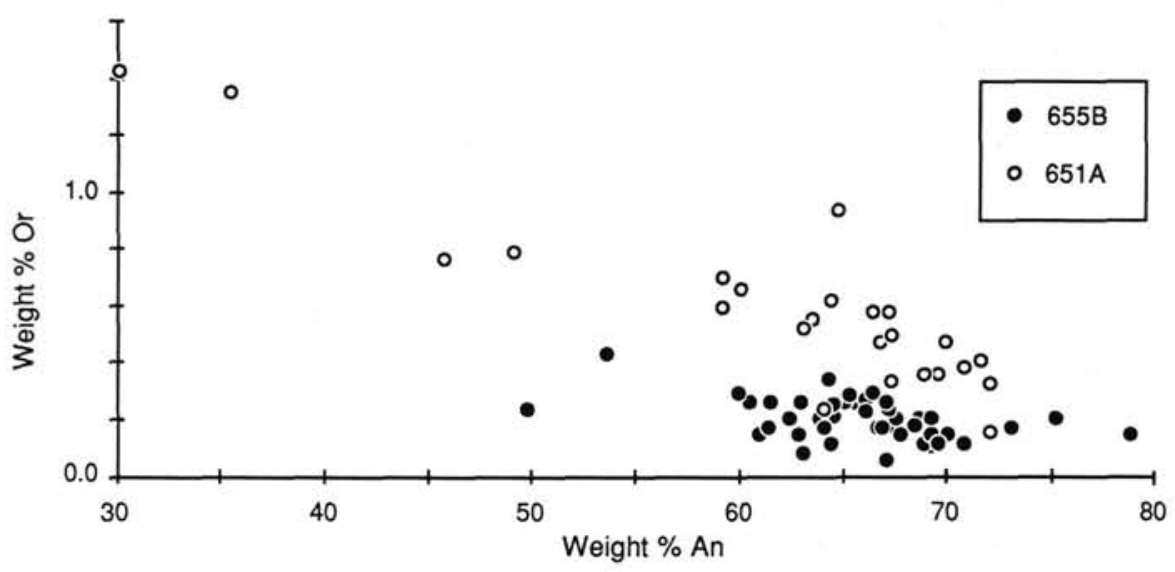

Figure 7. Or vs. An plot for plagioclases from ODP Holes 651A and 655B.

et al., 1979; Saunders and Tarney, 1979; Marcelot et al., 1983; Tarney et al., 1981; Wood et al., 1982; Fryer et al., 1982; Gill et al., 1984). The evolution from the first type to the second one is mainly marked by the enrichment of LREE and most LILE $(\mathrm{Rb}, \mathrm{K}, \mathrm{Ba}, \mathrm{Th})$ relative to HREE and HFSE $(\mathrm{Nb}, \mathrm{Ta}, \mathrm{Zr}, \mathrm{Hf}$, $\mathrm{Ti}, \mathrm{Y}$ ). An easily detectable consequence is the appearance of a $\mathrm{Nb}$-negative anomaly on the corresponding spidergram. These features are about the same in back-arc basins lying in an oceanic or continental environment, except for a more pronounced $\mathrm{Nb}$ depletion in the second case (Holm, 1985). Moreover, scarce alkali basalts have been found in some back-arc basins (Dick et al., 1980; Wood et al., 1980).

Compared to these occurrences, Vavilov Basin basalts (Holes $651 \mathrm{~A}, 655 \mathrm{~B}$, and 373) appear as well-defined back-arc basalts. It is clear that they do not represent "normal" oceanic crust (i.e., N-MORB prevailing in major oceans). They are N-MORBlike in their contents in HREE and some HFSE (Ti, Zr, Y), but display a progressive enrichment with time (from Site 655 to 651 ) of LREE and some LILE (K and Rb) connected with the appearance of a negative $\mathrm{Nb}$-anomaly (Fig. 15). We think that such evolution is also discernible in mineral chemistry, in so far as primary $\mathrm{K}_{2} \mathrm{O}$ content of plagioclase increases from Site 655 to 651 (Fig. 7).

This kind of geochemical evolution cannot be produced by fractional crystallization of a single parental magma, nor by derivation from a unique mantle source through varying degrees of partial melting. For melting to be responsible would require the existence of a fractionating or residual mineral phase able to selectively remove $\mathrm{Nb}$ with respect to most LILE (Rb, K), LREE, and other HFSE such as $\mathrm{Zr}$ (which remains on the general slope of the pattern whatever the behavior of $\mathrm{Nb}$ ). Such a mineral is most unlikely, unless the $\mathrm{P}, \mathrm{T}$, and $\mathrm{H}_{2} \mathrm{O}$ influences, induced in an orogenic environment (Briqueu et al., 1984), play an important role. The development of a $\mathrm{Nb}$ depletion is common in several continental tholeiites (Dupuy and Dostal, 1984; Bertrand in press), and may reflect some crustal contamination, but this process is inconsistent with the oceanic type basement in the Tyrrhenian basin as deduced from geophysical investiga- 
Table 5. Representative analyses of biotites from sample D (Hole 651A).

\begin{tabular}{|c|c|c|c|c|c|c|c|c|c|c|}
\hline Sample & $\begin{array}{r}\text { 651A-D } \\
1\end{array}$ & 2 & 3 & 4 & 5 & 6 & 7 & 8 & 9 & 10 \\
\hline $\mathrm{SIO2}$ & 38.90 & 40.28 & 40.74 & 39.71 & 39.89 & 40.18 & 39.18 & 38.49 & 39.55 & 38.11 \\
\hline TIO2 & 2.02 & 3.96 & 3.09 & 3.26 & 4.12 & 3.40 & 4.30 & 3.70 & 3.62 & 3.99 \\
\hline Al203 & 11.87 & 11.42 & 11.72 & 11.66 & 11.63 & 11.86 & 11.98 & 13.16 & 12.08 & 13.58 \\
\hline $\mathrm{Cr} 2 \mathrm{O3}$ & 0.08 & 0.23 & 0.03 & 0.02 & 0.00 & 0.01 & 0.00 & 0.03 & 0.01 & 0.00 \\
\hline $\mathrm{FeO}$ & 16.76 & 14.27 & 18.40 & 19.07 & 15.20 & 18.13 & 17.04 & 12.77 & 18.68 & 14.35 \\
\hline MnO & 0.10 & 0.07 & 0.19 & 0.09 & 0.20 & 0.18 & 0.06 & 0.08 & 0.05 & 0.05 \\
\hline $\mathrm{MgO}$ & 16.10 & 16.61 & 13.55 & 13.31 & 16.26 & 14.55 & 14.87 & 17.43 & 12.69 & 16.36 \\
\hline $\mathrm{CaO}$ & 0.38 & 0.21 & 0.35 & 0.17 & 0.07 & 0.15 & 0.00 & 0.14 & 0.05 & 0.06 \\
\hline $\mathrm{Na2O}$ & 0.25 & 0.53 & 0.46 & 0.41 & 0.53 & 0.43 & 0.41 & 0.86 & 0.37 & 0.65 \\
\hline K20 & 6.60 & 8.46 & 8.02 & 7.99 & 9.12 & 8.02 & 9.13 & 8.78 & 7.93 & 8.89 \\
\hline Total & 93.06 & 96.04 & 96.55 & 95.69 & 97.02 & 96.91 & 96.97 & 95.44 & 95.03 & 96.04 \\
\hline SI & 5.711 & 5.913 & 6.033 & 5.963 & 5.848 & 5.927 & 5.797 & 5.677 & 5.961 & 5.626 \\
\hline $\mathrm{TI}$ & 0.496 & 0.437 & 0.344 & 0.368 & 0.454 & 0.377 & 0.478 & 0.410 & 0.410 & 0.443 \\
\hline Al & 2.159 & 1.976 & 2.045 & 2.064 & 2.010 & 2.062 & 2.089 & 2.288 & 2.146 & 2.363 \\
\hline $\mathrm{Cr}$ & 0.004 & 0.027 & 0.004 & 0.002 & 0.000 & 0.001 & 0.000 & 0.003 & 0.001 & 0.000 \\
\hline $\mathrm{Fe} 2+$ & 1.893 & 1.752 & 2.279 & 2.395 & 1.864 & 2.236 & 2.108 & 1.575 & 2.355 & 1.772 \\
\hline Mn & 0.011 & 0.009 & 0.024 & 0.011 & 0.025 & 0.022 & 0.008 & 0.010 & 0.006 & 0.006 \\
\hline $\mathrm{Mg}$ & 3.495 & 3.634 & 2.991 & 2.979 & 3.553 & 3.199 & 3.279 & 3.832 & 2.851 & 3.600 \\
\hline $\mathrm{Ca}$ & 0.006 & 0.033 & 0.056 & 0.027 & 0.011 & 0.024 & 0.000 & 0.022 & 0.008 & 0.009 \\
\hline $\mathrm{Na}$ & 0.184 & 0.151 & 0.132 & 0.119 & 0.151 & 0.123 & 0.118 & 0.246 & 0.108 & 0.185 \\
\hline K & 1.680 & 1.584 & 1.515 & 1.531 & 1.706 & 1.509 & 1.723 & 1.652 & 1.525 & 1.674 \\
\hline Total & 15.639 & 15.516 & 15.423 & 15.459 & 15.622 & 15.480 & 15.600 & 15.715 & 15.371 & 15.678 \\
\hline
\end{tabular}

Table 6. Representative analyses of spinels (1-2) and ilmenite (3-5) from Hole 651A.

\begin{tabular}{|c|c|c|c|c|c|}
\hline Samples & $\begin{array}{r}651 A-C \\
1\end{array}$ & 2 & $\begin{array}{r}\text { 651A-D } \\
3\end{array}$ & 4 & 5 \\
\hline SIO2 & 2.14 & 1.73 & 0.10 & 0.08 & 0.10 \\
\hline TIO2 & 1.15 & 0.93 & 48.91 & 48.80 & 49.16 \\
\hline Al2O3 & 21.73 & 21.07 & 0.07 & 0.02 & 0.07 \\
\hline $\mathrm{Cr} 2 \mathrm{O3}$ & 39.58 & 40.58 & 0.00 & 0.03 & 0.25 \\
\hline $\mathrm{Fe} 2 \mathrm{O} 3$ & 3.59 & 3.62 & 6.77 & 6.78 & 5.71 \\
\hline $\mathrm{FeO}$ & 19.09 & 21.25 & 42.00 & 41.75 & 42.09 \\
\hline MnO & 0.24 & 0.29 & 1.76 & 1.85 & 1.91 \\
\hline $\mathrm{MgO}$ & 13.18 & 11.18 & 0.18 & 0.20 & 0.17 \\
\hline Total & 100.70 & 100.65 & 99.79 & 99.51 & 99.46 \\
\hline SI & 0.522 & 0.429 & 0.005 & 0.004 & 0.005 \\
\hline Al & 6.245 & 6.160 & 0.004 & 0.001 & 0.004 \\
\hline Cr & 7.630 & 7.958 & 0.000 & 0.001 & 0.010 \\
\hline Fe3+ & 0.658 & 0.676 & 0.258 & 0.259 & 0.218 \\
\hline $\mathrm{Fe} 2+$ & 3.891 & 4.406 & 1.779 & 1.774 & 1.788 \\
\hline Mn & 0.050 & 0.061 & 0.076 & 0.080 & 0.082 \\
\hline Mg & 4.792 & 4.135 & 0.014 & 0.015 & 0.013 \\
\hline$\pi$ & 0.211 & 0.174 & 1.864 & 1.865 & 1.879 \\
\hline Total & 23.999 & 23.998 & 4.000 & 4.000 & 4.000 \\
\hline MG & 54.876 & 48.072 & 0.728 & 0.811 & 0.684 \\
\hline
\end{tabular}

tions (Steinmetz et al., 1983; Recq et al., 1984). Therefore, we infer that the appearance of the negative $\mathrm{Nb}$-anomaly observed in upper basalts of Hole $651 \mathrm{~A}$ implies chemical modification of their mantle source, likely linked to the geodynamic environment. In oceanic context, the occurrence of a $\mathrm{Nb}$ anomaly is strictly related, on the basis of present knowledge, to island-arc lavas (Briqueu et al., 1984) or BAB (Saunders and Tarney, 1984), i.e., volcanics erupted close to a subducting plate. According to ideas reported in discussions on BAB genesis (Saunders and Tarney, 1979, 1984; Tarney et al., 1981; Wood et al., 1980), we interpret both LILE enrichment and negative Nbanomaly as the result of the migration of LILE-enriched hydrous fluids released by the subducted plate adjacent to the Tyrrhenian Sea, to the mantle source region of Vavilov Basin basaltic basement. In this way, the most mobile incompatible elements, (i.e., $\mathrm{Rb}, \mathrm{K}, \mathrm{La}$ ) are preferentially concentrated relative to less mobile HREE and HFSE, such as $\mathrm{Nb}$ which gradually displays a negative anomaly. Such a process is supported by recent dehydration experiments (Tatsumi et al., 1986), which have shown that an element with a larger ionic radius is more readily transported by an aqueous fluid. Quantification shows a maximum of mobility for $\mathrm{Cs}, \mathrm{Rb}, \mathrm{Ba}, \mathrm{K}, \mathrm{La}$ (in decreasing order), with $\mathrm{Nb}$ remaining immobile.

Finally, the observed geochemical evolution within Vavilov Basin allows us to propose the following geodynamic reconstruction.

1. Moderately LILE-enriched basalts from Hole $655 \mathrm{~B}$ record the early stage of volcanic activity in the basin (Féraud, this volume), together with those of Site 373. Considering their symmetric position with respect to the presumed spreading axis and their chemical similarity, together they may represent the early subcontemporaneous stage of back-arc spreading. We infer that they were generated from a N-type MORB mantle 
Table 7. Major elements (wt \%) and CIPW norms of basalts from Holes 655B and 651A. Vavilov seamount analyses are from Robin et al. (1987). Norms and $\mathbf{M g}$ ' $(=\mathrm{Mg} /(\mathrm{Mg}+\mathrm{Fe})$ atomic ratios $)$ are calculated with $\mathrm{Fe}^{3+} / \mathrm{Fe}^{2+}$ standardized to 0.15 .

\begin{tabular}{|c|c|c|c|c|c|c|c|c|c|c|c|c|}
\hline & \multicolumn{6}{|c|}{ HOLE $655 B$} & \multicolumn{3}{|c|}{ HOLE $651 \mathrm{~A}$} & \multicolumn{3}{|c|}{ VAVILOV } \\
\hline & $L$ & G & $\mathrm{J}$ & $M$ & $\mathrm{H}$ & $\mathrm{N}$ & $\mathrm{C}$ & D & E & 3.2 & 3.3 & 3.4 \\
\hline $\mathrm{SiO}_{2}$ & 47.20 & 44.20 & 48.50 & 48.30 & 45.70 & 47.25 & 46.40 & 49.15 & 46.65 & 47.70 & 49.00 & 47.70 \\
\hline $\mathrm{Al}_{2} \mathrm{O}_{3}$ & 17.25 & 15.60 & 16.40 & 16.10 & 17.40 & 17.85 & 17.20 & 16.50 & 17.00 & 17.45 & 17.50 & 17.00 \\
\hline $\mathrm{Fe}_{2}^{2} \mathrm{O}_{3}^{3}$ & 6.18 & 2.51 & 3.35 & 5.25 & 6.40 & 6.68 & 6.56 & 4.74 & 6.84 & 3.49 & 3.73 & 3.24 \\
\hline Fed 3 & 2.45 & 5.49 & 4.91 & 2.79 & 2.79 & 2.45 & 2.20 & 3.03 & 1.59 & 6.50 & 5.65 & 6.81 \\
\hline MgO & 6.07 & 6.87 & 6.73 & 6.70 & 5.40 & 5.93 & 5.30 & 8.33 & 7.90 & 8.06 & 7.40 & 7.90 \\
\hline $\mathrm{CaO}$ & 11.05 & 13.90 & 11.00 & 11.10 & 11.40 & 10.73 & 12.10 & 7.93 & 7.30 & 7.25 & 7.60 & 7.80 \\
\hline $\mathrm{Na}_{2} \mathrm{O}$ & 3.50 & 3.40 & 3.60 & 3.60 & 3.55 & 3.50 & 4.80 & 3.30 & 3.40 & 3.60 & 3.90 & 3.90 \\
\hline $\mathrm{K}_{2} \mathrm{O}$ & .20 & .25 & .35 & .25 & .30 & .25 & .40 & 1.75 & .70 & 1.12 & 1.40 & 1.20 \\
\hline $\mathrm{TiO}^{2}$ & 1.40 & 1.40 & 1.35 & 1.40 & 1.90 & 1.40 & 1.30 & 1.35 & 1.35 & 2.35 & 2.30 & 2.30 \\
\hline $\mathrm{P}_{2} \mathrm{O}_{5}^{2}$ & .10 & & .09 & .11 & .15 & .15 & .18 & .19 & .16 & & & \\
\hline $\mathrm{MnO}^{2}$ & .13 & .14 & .18 & .15 & .18 & .16 & .12 & .14 & .11 & .17 & .16 & .17 \\
\hline LOI & 4.61 & 6.59 & 3.06 & 4.01 & 4.30 & 4.21 & 4.50 & 3.90 & 6.45 & 1.85 & 1.34 & 1.46 \\
\hline TOTAL & 100.14 & 100.35 & 99.52 & 99.76 & 99.47 & 100.56 & 101.04 & 100.31 & 99.45 & 99.54 & 99.98 & 99.48 \\
\hline Mg' & 0.61 & 0.65 & 0.64 & 0.65 & 0.57 & 0.60 & 0.58 & 0.71 & 0.68 & 0.64 & 0.63 & 0.63 \\
\hline$Q$ & 0.00 & 0.00 & 0.00 & 0.00 & 0.00 & 0.00 & 0.00 & 0.00 & 0.00 & 0.00 & 0.00 & 0.00 \\
\hline or & 1.18 & 1.48 & 2.07 & 1.48 & 1.77 & 1.48 & 2.36 & 10.33 & 4.13 & 6.61 & 8.26 & 7.08 \\
\hline $\mathrm{Ab}$ & 26.41 & 9.34 & 27.36 & 28.02 & 22.17 & 26.96 & 16.81 & 27.90 & 28.75 & 29.27 & 29.25 & 26.23 \\
\hline An & 30.74 & 26.55 & 27.54 & 27.01 & 30.63 & 32.23 & 24.19 & 25.02 & 29.04 & 28.13 & 26.09 & 25.32 \\
\hline $\mathrm{Ne}$ & 1.72 & 10.52 & 1.67 & 1.31 & 4.25 & 1.43 & 12.88 & 0.00 & 0.00 & .63 & 2.02 & 3.65 \\
\hline Ap & .24 & 0.00 & .21 & .26 & .35 & .35 & .43 & .45 & .38 & 0.00 & 0.00 & 0.00 \\
\hline Di & 19.08 & 34.30 & 21.47 & 22.16 & 20.42 & 16.39 & 28.42 & 10.59 & 5.01 & 6.32 & 9.37 & 10.81 \\
\hline Hy & 0.00 & 0.00 & 0.00 & 0.00 & 0.00 & 0.00 & 0.00 & .18 & 6.11 & 0.00 & 0.00 & 0.00 \\
\hline 01 & 10.39 & 6.81 & 11.37 & 10.55 & 9.33 & 12.21 & 6.46 & 17.17 & 14.51 & 19.63 & 16.76 & 17.92 \\
\hline Mt & 1.93 & 1.87 & 1.91 & 1.81 & 2.06 & 2.04 & 1.96 & 1.76 & 1.87 & 2.33 & 2.17 & 2.35 \\
\hline I1 & 2.66 & 2.66 & 2.57 & 2.66 & 3.61 & 2.66 & 2.47 & 2.57 & 2.57 & 4.47 & 4.38 & 4.38 \\
\hline
\end{tabular}

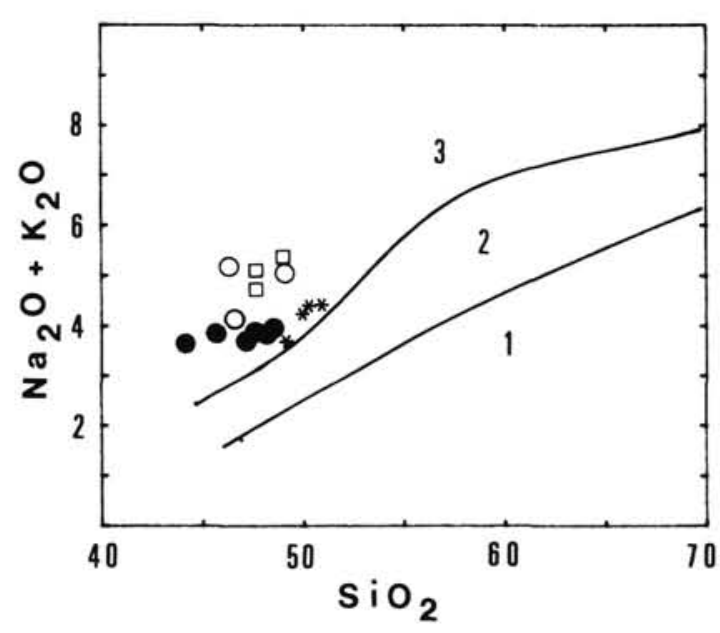

Figure 8. Alkali vs. silica diagram (wt \%) for basalts from ODP Holes $651 \mathrm{~A}$ and $655 \mathrm{~B}$. The solid lines represent the limits of tholeiitic (field 1 ), high alumina (field 2), and alkali basalts (field 3) series of Japan (Kuno, 1968) . Open circles $=$ Hole $651 \mathrm{~A}$; filled circles $=$ Hole $655 \mathrm{~B} ;$ stars $=$ high-Ti group from Leg 42 Site 373 (Barberi et al., 1978). Squares = Vavilov Seamount (Robin et al., 1987).

source slightly enriched in LILE by fluids supplied by the subducted slab (moderate influence).

2. The only one available analysis of the lower basalts from Hole $651 \mathrm{~A}$, located at the axis of the basin, suggests that these basalts may be rather similar to the former and could reflect some continuity with time(?) of source composition.

3. The eruption of upper basalts at the same Hole $651 \mathrm{~A}$, which are more recent (Féraud, this volume), highly LILE-en-

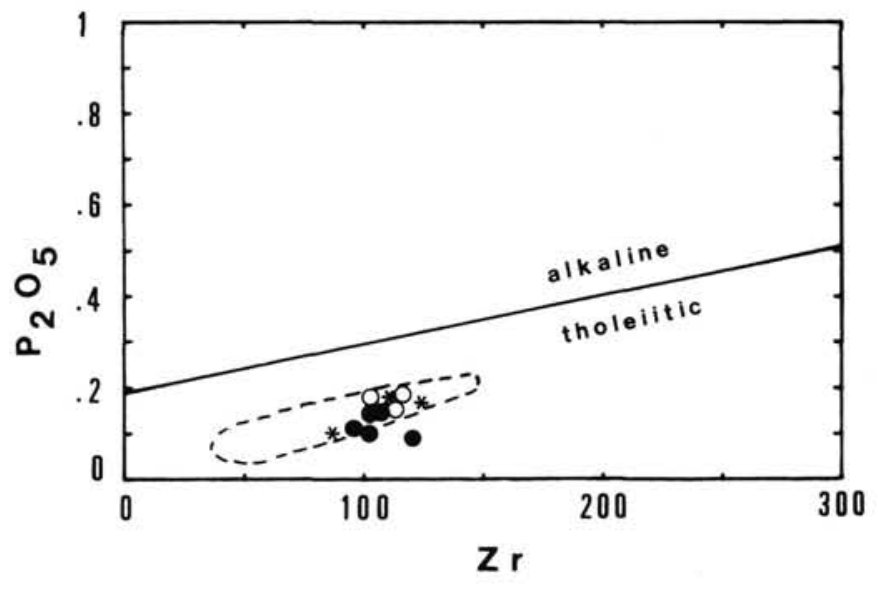

Figure 9. $\mathrm{P}_{2} \mathrm{O}_{5}$ (wt \%) vs. $\mathrm{Zr}$ (ppm) plot of basalts from ODP Holes $651 \mathrm{~A}$ and $655 \mathrm{~B}$, with divide between tholeiitic and alkaline lavas (after Floyd and Winchester, 1975). Symbols same as for Figure 8. The dashed line delineates the reference field for selected back-arc basalts (BAB) from Parece Vela and West Philippines Basins (Wood et al., 1981), Mariana Trough (Wood et al., 1982), Lau Basin (Gill, 1976), Bransfield Strait (Weaver et al., 1979), and East Scotia Sea (Saunders and Tarney, 1979).

riched, and exhibit a negative $\mathrm{Nb}$-anomaly implies incorporation within their mantle source of an important fluid component released from adjacent downgoing slab whose geometry may have become stable, indicating a maturation of subduction, according to Saunders and Tarney (1984). The somewhat higher observed enrichment relative to Pacific BAB could be explained, in our opinion, by the fact that the Vavilov Basin is a 


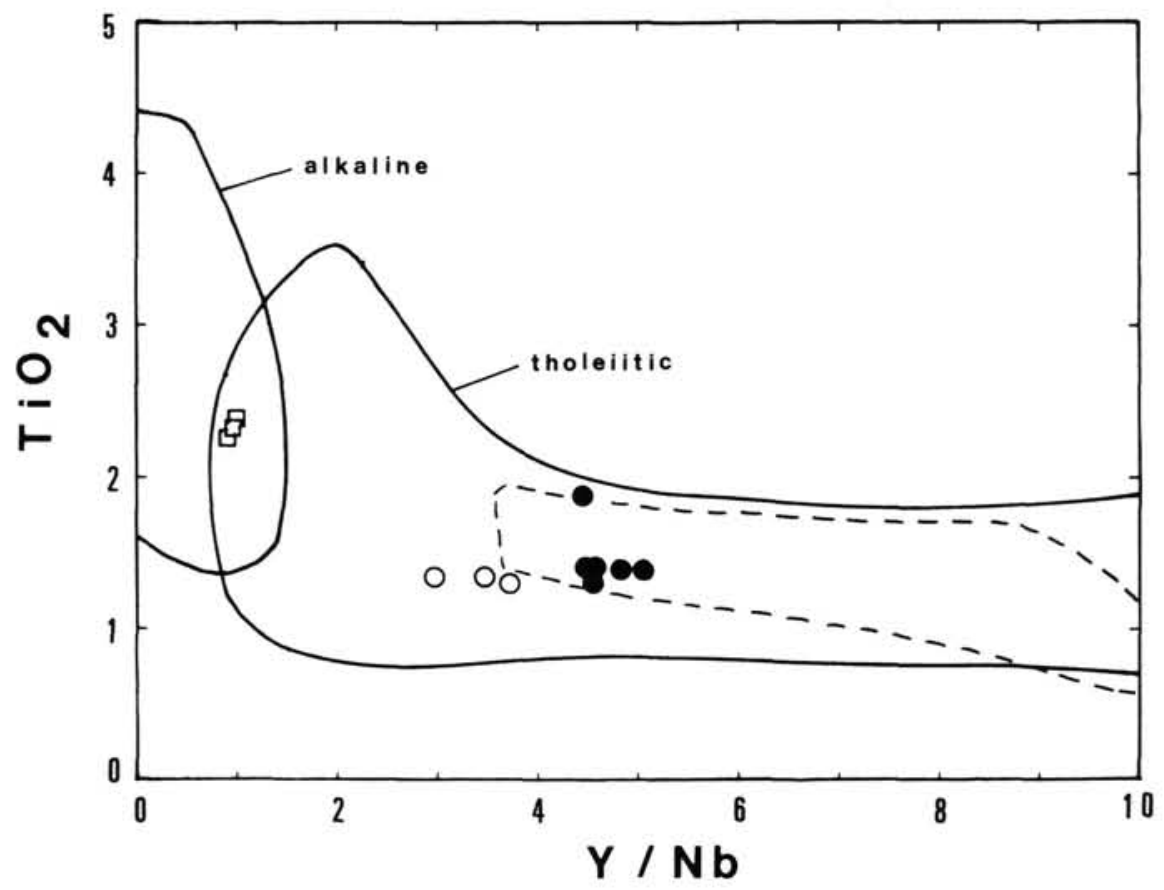

Figure $10 . \mathrm{TiO}_{2}(\mathrm{wt} \%)$ vs. Y/Nb plot of basalts from ODP Holes $651 \mathrm{~A}$ and $655 \mathrm{~B}$, with tholeiitic and alkaline fields. Dashed line $=$ reference field for BAB. Symbols are those used in Figure 8. (After Floyd and Winchester, 1975.)

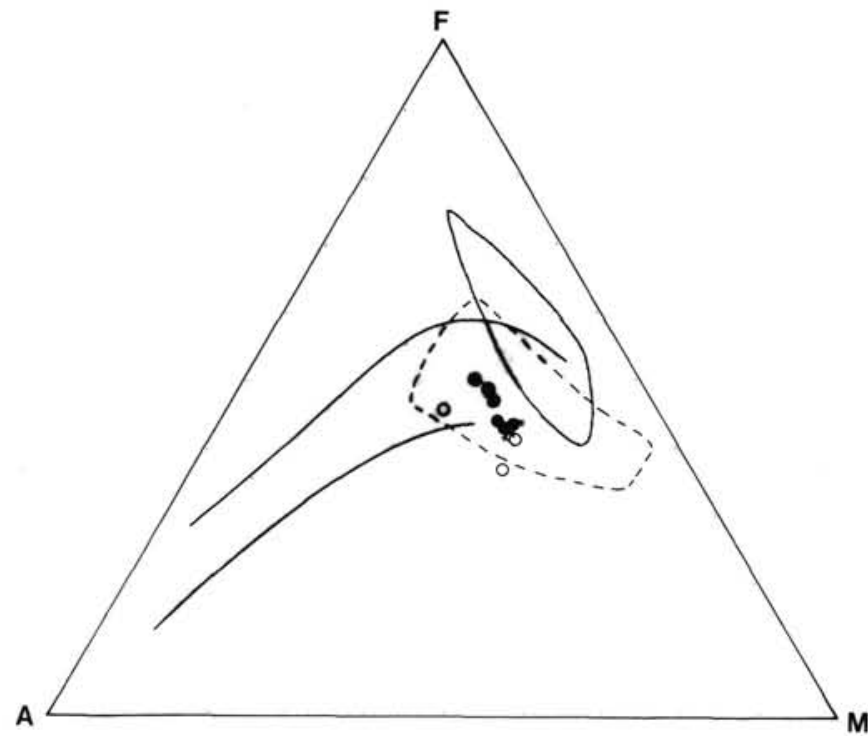

Figure 11. AFM $\left(\mathrm{Na}_{2} \mathrm{O}+\mathrm{K}_{2} \mathrm{O}-\mathrm{FeO}\right.$ total-MgO) diagram for ODP Holes $651 \mathrm{~A}$ and $655 \mathrm{~B}$ basalts. Solid line delineates the general field of MORB. Dashed line $=$ reference field for BAB. Shaded field corresponds to calc-alkaline lavas from Japan (Kuno, 1968). Other symbols same as for Figure 8.

narrow ensialic basin, opened just against a continental margin, and intimately associated with the subduction zone. Such conditions favor the contribution of subducted components in the genesis of back-arc basalts. The thickness of the downgoing African plate, and more specially of its sediment column, greater than in Pacific cases, may be fundamental in production of the inferred fluids. Such a contribution could be better evaluated using isotopic data.
4. The only younger volcanics known within Vavilov Basin are those of Vavilov seamount (Robin et al., 1987), located in the same axial position as Hole $651 \mathrm{~A}$ basalts. However the present study underlines their specific composition, because of the vanishing of $\mathrm{Nb}$ negative anomaly, the slope of their spidergrams, their mild alkaline character and within plate OIB tendency. These features would require generation from another mantle source, and it may be supposed that eruption of this volcano is a consequence of an important change in the evolution of the Tyrrhenian Sea, possibly subsequent to a blocking of the system. It is reasonable to attribute the vanishing of the $\mathrm{Nb}$ anomaly to the cessation of downgoing slab influence, which appears consistent with the progressive southeastward retreat of the subduction evidenced by Ritsema (1979), Moussat (1983), Malinverno and Ryan (1986), and Rehault et al. (1987). If slab influence continues, then magmas must have been extracted from another mantle level, preserved from any subduction influence. The emplacement of the Vavilov seamount could be an expression of a late off-axis activity, comparable to alkali sills in Daito Basin (Dick et al., 1980), on the immature yet fossil spreading axis of the basin. Active back-arc spreading appears to continue, however, in Marsili Basin.

\section{SUMMARY AND CONCLUSIONS}

1. Basalts erupted in Vavilov Basin at Holes 651A and 655B have compositions consistent with their back-arc setting. Their major element abundances lie within the range of N-MORB except for $\mathrm{Na}_{2} \mathrm{O}$ and $\mathrm{K}_{2} \mathrm{O}$. They are comparable to Pacific backarc basalts.

2. On the basis of hygromagmaphile elements, basalts display contrasting compositions in the two sites. Basalts from Hole 655B are E-MORB-like, those from Hole 651A progressively acquire calc-alkaline characteristics as evidenced by the increase of LILE/HFSE ratio and appearance of a negative $\mathrm{Nb}$ anomaly. 


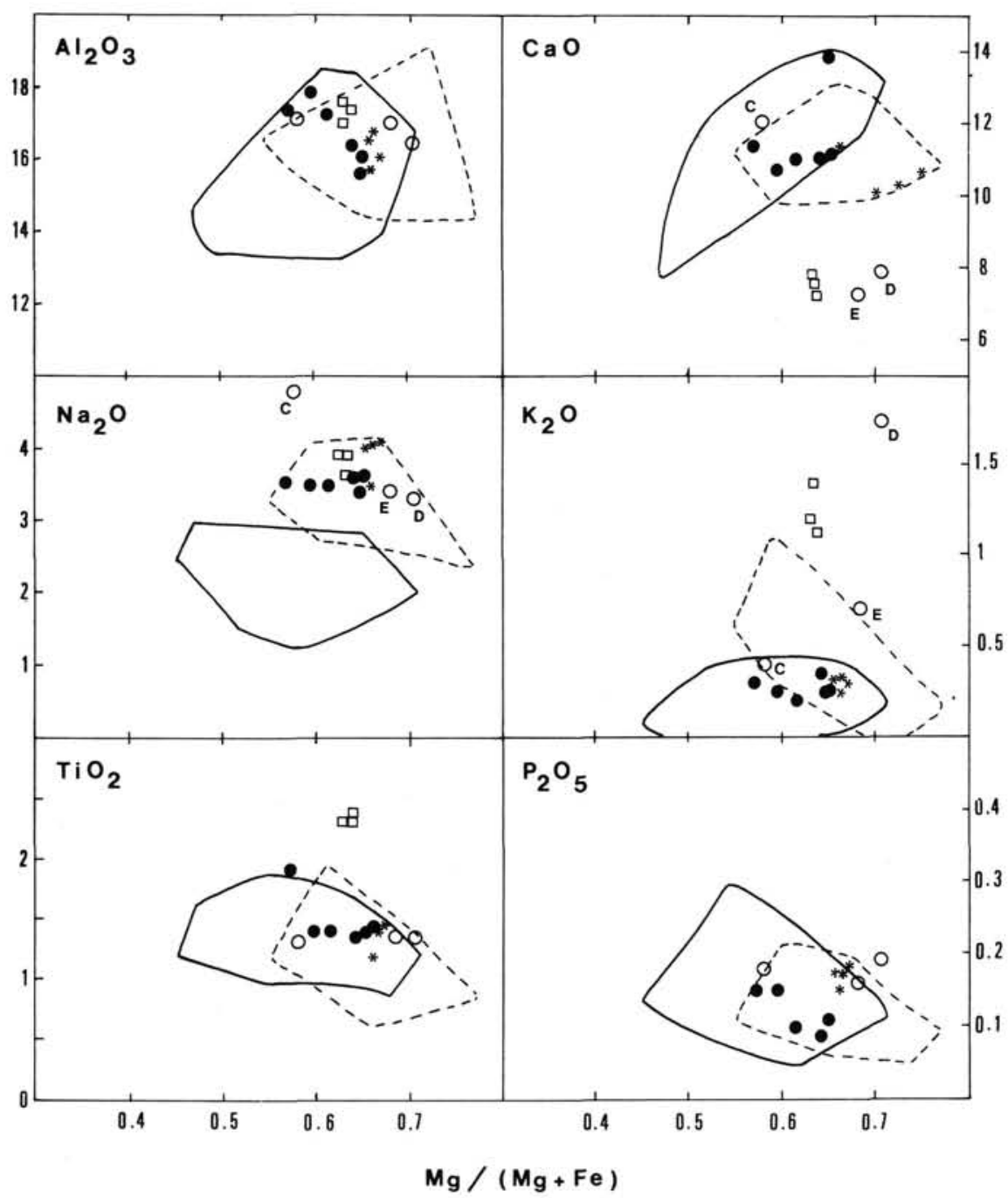

Figure 12. Major element oxides (wt $\%)$ vs. $\mathrm{Mg}$-value $(\mathrm{Mg} /(\mathrm{Mg}+\mathrm{Fe})$ for basalts from ODP Holes $651 \mathrm{~A}$ and $655 \mathrm{~B}$. The symbols are as in Figure 8. Dashed line $=$ reference field for BAB. $\mathrm{N}-\mathrm{MORB}$ field (solid line) is defined from Atlantic Ocean between $33^{\circ} \mathrm{N}$ and $56^{\circ} \mathrm{N}=$ data from Ayuso et al., 1976, and Bryan et al., 1977 (DSDP Leg 11); Flower et al., 1977; Lambert and Holland, 1977; Blanchard et al., 1976; Gunn and Roobol, 1977 (DSDP Leg 37); Maury et al., 1985 (DSDP Leg 80); Harrison et al., 1984, Joron et al., 1984; Richardson et al., 1984 (DSDP Leg 81). Samples C, D, and E from Hole 651A.

3. The observed chemical compositions of the basalts are compatible with a derivation of the magmas from a N-MORB type source progressively contaminated by LILE enriched fluids released from dehydration of the adjacent subducted plate. Such evolution toward pronounced calc-alkaline characteristics exemplify the behavior of a small ensialic basin wedged between a continental margin and a subducted plate, as it is the case in Bransfield Strait (Saunders and Tarney, 1984), and possibly the contribution of the important sedimentary component of the subducted plate.

4. The evolution with time of Leg 107 basalts, combined with data from Leg 42 and Vavilov seamount, provide a valuable magmatic marker of the geodynamic evolution of the Tyrrhenian Sea. The volcanic activity presumably records back-arc spreading closely associated with the maturation of the adjacent subduction, followed by a late off-axis OIB-like central volcano possibly subsequent to a modification of plate motion and the southeastward retreat of the active subduction.

\section{ACKNOWLEDGMENTS}

The authors are grateful to Drs. Floyd W. McCoy, Kim A. Kastens, and Jean Mascle for constructive and helpful comments for the elaboration of the final manuscript.

\section{REFERENCES}

Ayuso, R. A., Bence, A. E., and Taylor, S. R., 1976. Upper Jurassic tholeitic basalts from DSDP Leg 11. J. Geophys. Res., 81:43054325.

Barberi, F., Gasparini, P., Innocenti, F., and Villari, L., 1973. Volcanism of the southern Tyrrhenian Sea and its geodynamic implications. J. Geophys. Res., 78:5221-5232.

Barberi, F., Innocenti, F., Ferrara, G., Keller, J., and Villari, L., 1974. Evolution of Eolian arc volcanism (southern Tyrrhenian Sea). Earth Planet. Sci. Lett., 21:269-276.

Barberi, F., Bizouard, B., Capaldi, G., Ferrara, G., Gasparini, P., Innocenti, F., Joron, J. L., Lambret, B., Treuil, M., and Allégre, C., 1978. Age and nature of basalts from the Tyrrhenian abyssal plain. 
In Hsü, K. J., Montadert, L., et al., Init. Repts. DSDP, 42: Washington (U.S. Govt. Printing Office), 509-514.

Beccaluva, L., Rossi, P. L., and Serri, G., 1982. Neogene to Recent Volcanism of the Southern Tyrrhenian-Sicilian Area: Implications for the Geodynamic Evolution of the Calabrian Arc. Earth Evol. Sci., 3:222-238.

Beccaluva, L., Gabbianelli, G., Lucchini, F., Rossi, P. L., and Savelli, C., 1985. Petrology and $\mathrm{K} / \mathrm{Ar}$ ages of volcanics dredged from the Eolian seamounts: implications for geodynamic evolution of the southern Tyrrhenian basin. Earth Planet. Sci. Lett., 74:187-208.

Bertrand, B., 1988. Les diagrammes discriminants permettent ils de reconstituer le Site géodynamique de mise en place de formations paléovolcaniques? C.R. Acad. Sci. Paris, 306:33-38.

in press. The Mesozoic tholeiitic province of northwest Africa: A volcano tectonic record of the early opening of Central Atlantic. In Kampunzu, A. B. (Ed.) Extensive magmatism and structural setting. Berlin (Springer Verlag).

Blanchard, D. P., Rhodes, J. M., Dungan, M. A., Rodger, K. V., Donaldson, G. B., Brannon, J. G., Jacobs, J. W., and Gibson, E. K., 1978. The chemistry and petrology of basalts from the Leg 37 of the DSDP. J. Geophys. Res., 81:4231-4246.

Boccaletti, M., and Guazzone, G., 1972. Gli archi apennici, il Mar Ligure ed il Mar Tirreno nel quadro della tettonica dei bacini marginali retro-arco. Mem. Soc. Geol. It., 11:201-216.

Boivin, P., 1982. Intéractions entre magmas basaltiques et manteau supérieur : arguments apportés par les enclaves basiques des basaltes alcalins. Exemple du Devés (Massif Central Français) et du volcanisme quaternaire de la région de Carthagéne (Espagne). [Ph.D. dissert.]. Univ. Clermont Ferrand.

Briqueu, L., Bougault, B., and Joron, J. L., 1984. Quantification of $\mathrm{Nb}, \mathrm{Ta}, \mathrm{Ti}$ and $\mathrm{V}$ anomalies in magmas associated with subduction zones. Petrogenetic implications. Earth Planet. Sci. Lett., 68:297308.

Bryan, W. B., Frey, F. A., and Thompson, G., 1977. Oldest atlantic seafloor: Mesozoic basalts from western North Atlantic margin and eastern north America. Contrib. Mineral. Petrol., 64:223-242.

Della Vedova, B., Pellis, G., Foucher, J. P., and Rehault, J. P., 1984. Geothermal structure of the Tyrrhenian Sea. Mar. Geol., 55:271289.

Dick, B.J.B., Marsh, N. G., and Bullen, T. D., 1980. Deep Sea drilling project leg 58 abyssal basalts from the Shikoku basin: Their petrology and major element geochemistry. In Klein, G. deV., Kobayashi, K., et al., Init. Repts. DSDP, 58: Washington (U.S. Govt. Printing Office), 843-870.

Dietrich, V., Emmermann, R., Keller, J., and Puchelt, B., 1977. Tholeiitic basalts from the Tyrrhenian Sea floor. Earth Planet. Sci. Lett., 36:285-296.

Dupuy, G., Dostal, J., Girod, M., and Liotard, M., 1981. Origin of volcanic rocks from Stromboli (Italy). J. Volcanol. Geotherm. Res., 10: 49-65.

Dupuy, G., and Dostal, J., 1984. Trace element geochemistry of some continental tholeiites. Earth Planet. Sci. Lett., 67:61-69.

Flower, M.F.J., Robinson, P. T., Schmincke, B. V., and Ohnmacht, W., 1977. Petrology and geochemistry of igneous rocks D.S.D.P. Leg 37. In Aumento, F., Melson, W. G., et al., Init. Repts. DSDP, 37: Washington (U.S. Govt. Printing Office), 653-679.

Floyd, P. A., and Winchester, J. A., 1975. Magma type and tectonic setting discrimination using immobile elements. Earth Planet. Sci. Lett., 27:211-218.

Fryer, P., Sinton, J. M., and Philpotts, J. A., 1982. Basaltic glasses from the Mariana Trough. In Hussong,D. M., Uyeda, S., et al., Init. Repts. DSDP, 60, Washington (U.S. Govt. Printing Office), 601-609.

Gamble, R. P., and Taylor, L. A., 1980. Crystal/liquid partitioning in augite: Effects of cooling rate. Earth Planet. Sci. Lett., 47:21-33.

Gasparini, G., Iannacone, I., Scandone, P., and Scarpa, R., 1982. Seismotectonics of the Calabrian Arc. Tectonophysics, 84:267-286.

Gill, J. B., 1978. Composition and age of Lau Basin and Ridge volcanic rocks: Implications for evolution of an inter-arc basin and remnant arc. Geol. Soc. Am. Bull., 87:1384-1395.

Gill, J. B., Stork, A. L., and Whelan, P. M., 1984. Volcanism accompanying back-arc basin development in the southwest Pacific. Tectonophysics, 102:207-224.
Gunn, B., and Roobol, M. J., 1977. Geochemistry of the igneous rocks. In Aumento, F., Melson, W. G., et al., Init. Repts. DSDP, 37: Washington (U.S. Govt. Printing Office), 735-757.

Hamelin, B., Lambret, B., Joron, J. L., Treuil, M., and Allègre, G. J., 1979. Geochemistry of basalts from the Tyrrhenian Sea. Nature, 278:832-834.

Harrison, R. K., Merriman, R. J., et al. 1984. Petrology, mineralogy, and geochemistry of basaltic rocks: Leg 81 . In Roberts, D. G., Schnitker, D., et al., Init. Repts. DSDP, 81: Washington (U.S. Govt. Printing Office), 743-774.

Holm, P. E., 1985. The geochemical fingerprints of different tectonomagmatic environments using hygromagmatophile element abundances of tholeiitic basalts and basaltic andesites. Chem. Geol., 51: 303-323.

Hutchison, I., 1983. Heat flow studies in the Gulf of Oman and western Mediterranean basins. [Ph.D. dissert.]. Univ. Cambridge.

Joron, J. L., Bougault, B., Maury, R. G., Bohn, M., and Desprairies, A., 1984. Strongly depleted tholeites from the Rockall plateau margin, north Atlantic: Geochemistry and mineralogy. In Roberts, D. G., Schnitker, D., et al., Init. Repts. DSDP, 81: Washington (U.S. Govt. Printing Office), 783-794.

Kastens, K., et al., 1986. La campagne 107 du Joides Resolution (Ocean Drilling Program) en Mer Tyrrhénienne: premiers résultats. C.R. Acad. Sci. Paris, 303:391-396.

Kastens, K., Mascle J., et al., 1987. Proc. ODP Init. Repts, 107: College Station, TX (Ocean Drilling Program).

Keller, J., 1974. Petrology of some volcanic rock series of the Aeolian arc, southern Tyrrhenian sea: Calc-alkaline and shoshonitic associations. Contrib. Mineral. Petrol., 46:29-47.

Kreuzer, B., Mohr, M., and Wenot, I., 1978. Potassium-argon age determination of basalt samples from leg $42 \mathrm{~A}$, hole 373 , core 7 . In Hsü, K. J., Montadert, L., et al., Init. Repts. DSDP, 42: Washington (U.S. Govt. Printing Office), 531-537.

Kuno, H., 1968. Differentiation of basalt magmas. In Hess, H. H., and Poldervaart, A. (Eds.), Basalts: New York (Interscience), 628-688.

Lambert, R., and Holland, J. G., 1977. Trace elements and petrogenesis of DSDP 37 basalts. Can. J. Earth Sci., 14:809-836.

Leterrier, J., Maury, R. G., Thonon, P., Girard, D., and Marchal, M., 1982. Clinopyroxene composition as a method of identification of the magmatic affinities of paleo-volcanic series. Earth Planet. Sci. Lett., 59:139-154.

Luais, B., 1988. Pétrologie et géochimie (éléments en trace et rapports isotopiques du $\mathrm{Sr}$ ) du magmatisme associé aux zones de subduction. Exemples du Bassin méditerranéen (Santorin, Arc Egéen; Stromboli, Arc Eolien) et des Iles de la Sonde (Mérapi, Java). [Ph.D. dissert.]. Univ. Montpellier.

Malinverno, A., and Ryan, B. F., 1988. Extension in the Tyrrhenian Sea and shortening in the Apennines as result of arc migration driven by sinking of the lithosphere. Tectonics, 5:227-245.

Marcelot, G., Dupuy, G., Girod, M., and Maury, R. G., 1983. Petrology of Futuna island lavas (New Hebrides): An example of calc-alkaline magmatism associated with the initial stages of back-arc spreading. Chem. Geol., 38:23-37.

Marsh, N. G., Tarney, J., and Dick, B.J.B., 1980. Geochemistry of basalts from the Shikoku and Daito Basins, Deep Sea Drilling Project Leg 58. In Klein, G. deV., Kobayashi, K., et al., Init. Repts. DSDP, 58: Washington (U.S. Govt. Printing Office), 805-842.

Maury, R. G., Bellon, B., Bougault, B., Joron, J. L., Bohn, M., and de Graciansky, P. C., 1985. Oceanic tholeiites from leg 80 Sites (Celtic Sea passive margin, northeastern Atlantic): Geochemistry and mineralogy. In de Graciansky, P. C., Poag, C. W., et al., Init. Repts. DSDP, 80, Washington (U.S. Govt. Printing Office), 939-946.

Moussat, E., 1983. Evolution de la Mer Tyrrhénienne centrale et orientale et de ses marges septentrionales en relation avec la néotectonique dans l'arc calabrais. [Ph.D. dissert.] Univ. Paris.

Moussat, E., Rehault, J. P., Fabbri, A., and Mascle, G., 1985. Evolution géologique de la Mer Tyrrhénienne. C.R. Acad. Sci. Paris, 301: 491-496.

Pearce, J. A., 1975. Basalt geochemistry used to investigate post tectonic environments on Cyprus. Tectonophysics, 25:41-67.

1982. Trace element characteristics of lavas from destructive plate boundaries. In Thorpe, R. S. (Ed.) Andesites. New York (Wiley), 525-548. 
Pearce, J. A., Cann, J. R., 1973. Tectonic setting of basic volcanic rocks determined using trace element analyses. Earth Planet. Sci. Lett., 19:290-300.

Pearce, J. A., Norry, M. J., 1979. Petrogenetic implications of Ti, Zr, Y and $\mathrm{Nb}$ variations in volcanic rocks. Contrib. Mineral. Petrol., 69: 33-47.

Recq, M., Rehault, J. P., Steinmetz, L., and Fabbri, A., 1984. Amincissement de la croute et accrétion au centre du bassin Tyrrhénien d'aprés la sismique réfraction. Mar. Geol., 55:411-428.

Rehault, J. P., Moussat, E., and Fabbri, A., 1987. Structural evolution of the Tyrrhenian back-arc basin. Mar. Geol., 74:123-150.

Richardson, G., Oakley, P. J., and Cann, J. R., 1984. Trace and major element geochemistry of basalts from Leg 81 . In Roberts, D. G., Schnitker, D., et al., Init. Repts. DSDP, 81: Washington (U.S. Govt. Printing Office), 795-806.

Ridley, W. I., Rhodes, J. M., Reid, A. M., Jakes, P., Shih, G., and Bass, M. N., 1974. Basalts from Leg 6 of the Deep-Sea Drilling Project. J. Petrol., 15:140-159.

Ritsema, A. R., 1979. Active or passive subduction at the Calabrian Arc. Geol. Mijnbouw, 58:127-134.

Robin, C., Gennesseaux, M., Colantoni, P., and Vanney, J. R., 1988. Le volcan sous-marin quaternaire Vavilov (mer Tyrrhénienne centrale). Résultats des plongées en submersible Cyana. C.R. Acad. Sci. Paris, 303:1665-1670.

Robin, C., Colantoni, P., Gennesseaux, M., and Rehault, J. P., 1987. Vavilov seamount : a mildly alkaline quaternary volcano in the Tyrrhenian Basin. Mar. Geol., 78:125-136.

Saunders, A. D., and Tarney, J., 1979. The geochemistry of basalts from a back-arc spreading centre in the East Scotia Sea. Geochim. Cosmochim. Acta, 43:555-572.

1984. Geochemical characteristics of basaltic volcanism within back-arc basins. In Kokelaar, B. P., and Howells, M. F., (Eds.) Marginal basin geology. Volcanic and associated sedimentary and tectonic processes in modern and ancient marginal basins, Oxford (Blackwell), 59-76.

Selli, R., Lucchini, F., Rossi, P., Savelli, G., and Del Monte, M., 1977. Dati geologici, petrochimici e radiometrici sui vulcani centro-Tirrenici. G. Geol., 42:221-246.

Seyfried, W. E., and Bischoff, J. L., 1979. Low temperature basalt alteration by seawater: an experimental study at $70^{\circ} \mathrm{C}$ and $150^{\circ} \mathrm{C}$. Geochim. Cosmochim. Acta, 43:1937-1947.

Seyfried, W. E., and Mottl, M. J., 1982. Hydrothermal alteration of basalt by seawater under seawater-domination conditions. Geochim. Cosmochim. Acta, 46:985-1002.

Sharaskin, A. Y., Bogdanov, N. A., and Zakariadze, G. S., 1981. Geochemistry and timing of the marginal basin and arc magmatism in the Philippine Sea. Phil. Trans. R. Soc. Lond., A300:287-297.

Shervais, J. W., 1982. Ti-V plots and the petrogenesis of modern and ophiolitic lavas. Earth Planet. Sci. Lett., 59:101-118.
Steinmetz, L., Ferruci, F., Birn, A., Morelli, G., and Nicolich, R., 1983. A $550 \mathrm{~km}$ long Moho traverse in the Tyrrhenian Sea from 0.B.S. recorded Pn waves. Geophys. Res. Lett., 10:428-431.

Sun, S., Nesbitt, R. W., and Sharaskin, A., 1979. Geochemical characteristics of mid-ocean ridge basalts. Earth Planet. Sci. Lett., 44:119138.

Tarney, J., Saunders, A. D., Mattey, D. P., Wood, D. A., and Marsh, N. G., 1981. Geochemical aspects of back-arc spreading in the Scotia Sea and Western Pacific. Phil. Trans. R. Soc. Lond., A300:263-285.

Tatsumi, Y., Hamilton, D. L., and Nesbitt, R. W., 1988. Chemical characteristics of fluid phase released from a subducted lithosphere and origin of arc magmas: Evidence from high pressure experiments and natural rocks. J. Volcanol. Geotherm. Res., 29:293-310.

Thompson, R. N., Dickin, A. P., Gibson, I. L., and Morrison, M. A., 1982. Elemental fingerprints of isotopic contamination of Hebridean palaeocene mantle derived magmas by archean sial. Contrib. Mineral. Petrol., 79:159-168.

Watson, E. B., 1979. Calcium content of forsterite coexisting with silicate liquid in the system $\mathrm{Na}_{2} \mathrm{O}-\mathrm{CaO}-\mathrm{MgO}-\mathrm{Al}_{2} \mathrm{O}_{3}-\mathrm{SiO}_{2} . A m$. Mineral., 64:824-829.

Weaver, S. D., Saunders, A. D., Pankhurst, R.J.W., and Tarney, J., 1979. A geochemical study of magmatism associated with the initial stages of back-arc spreading (the quaternary volcanics of Bransfield Strait from South Shetland Islands). Contrib. Mineral. Petrol., 68: 151-169.

Wood, D. A., Joron, J. L., Marsh, N. G., Tarney, J., and Treuil, M., 1980. Major- and trace-element variations in basalts from the North Philippine Sea drilled during Deep Sea Drilling Project Leg 58: A comparative study of back-arc basin basalts with lava series from Japan and Mid-ocean ridges. In Klein, G. deV., Kobayashi, K., et al., Init. Repts. DSDP, 58: Washington (U.S. Govt. Printing Office), 873-894.

Wood, D. A., Mattey, D. P., Joron, J. L., Marsh, N. G., Tarney, J., and Treuil, M., 1981. A geochemical study of 17 selected samples from basement cores recovered at Sites 447, 448, 449, 450 and 451, Deep Sea Drilling Project Leg 59. In Kroenke, L., Scott, R., et al., Init. Repts. DSDP, 59: Washington (U.S. Govt. Printing Office), 743752.

Wood, D. A., Marsh, N. G., Tarney, J., Joron, J. L., Fryer, P., and Treuil, M., 1982. Geochemistry of igneous rocks recovered from a transect across the Mariana Trough, arc, fore-arc, and trench, Sites 453 through 461, Deep Sea Drilling Project Leg 60. In Hussong, D. M., Uyeda, S., et al., Init. Repts. DSDP, 60, Washington (U.S. Govt. Printing Office), 611-645.

Date of initial receipt: 5 January 1988

Date of acceptance: 2 February 1989

Ms 107B-142 
Table 8. Trace elements (ppm) of basalts from Holes 655B and 651A. Vavilov seamount analyses are from Robin et al. (1987), except new analyses of $\mathrm{Nb}, \mathrm{Zr}, \mathbf{Y}$.

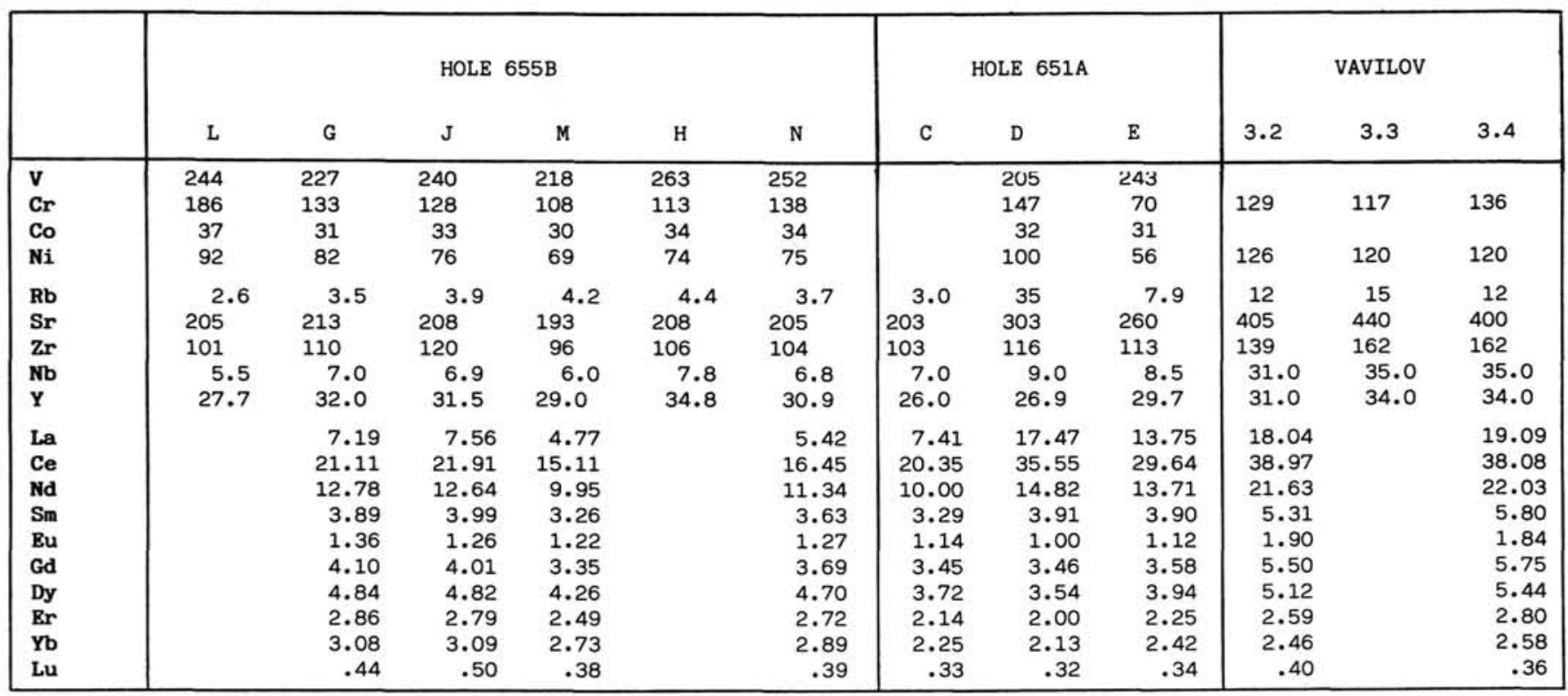

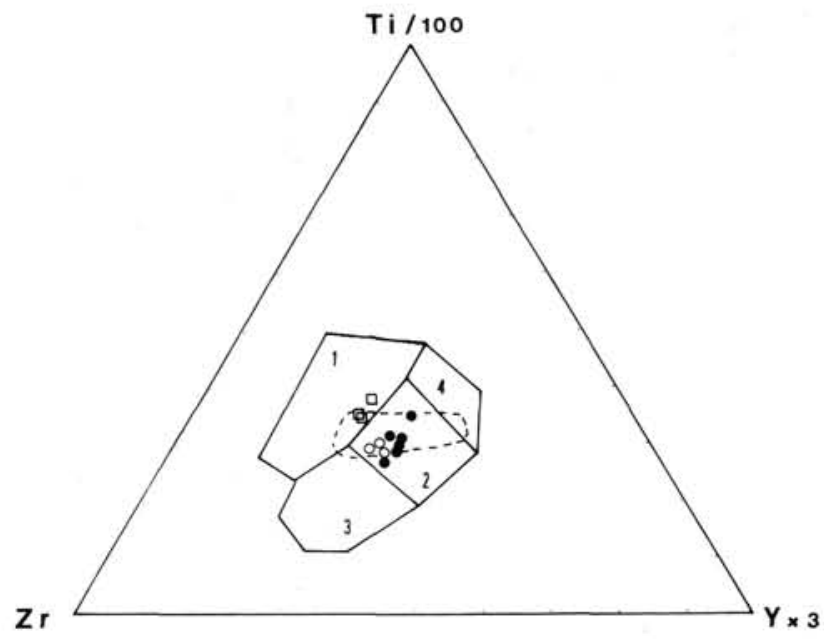

Figure 13. $\mathrm{Zr}-\mathrm{Ti} / 10 \mathrm{O}-\mathrm{Y} \times 3$ diagram for ODP Hole $651 \mathrm{~A}$ and $655 \mathrm{~B}$ basalts. Areas: 1 = within plate basalts; $2=$ MORB, $3=$ calc-alkaline basalts; $4=$ island arc tholeiites. Symbols same as for Figure 8. Dashed line $=$ reference field for BAB. (After Pearce and Cann, 1973.) 


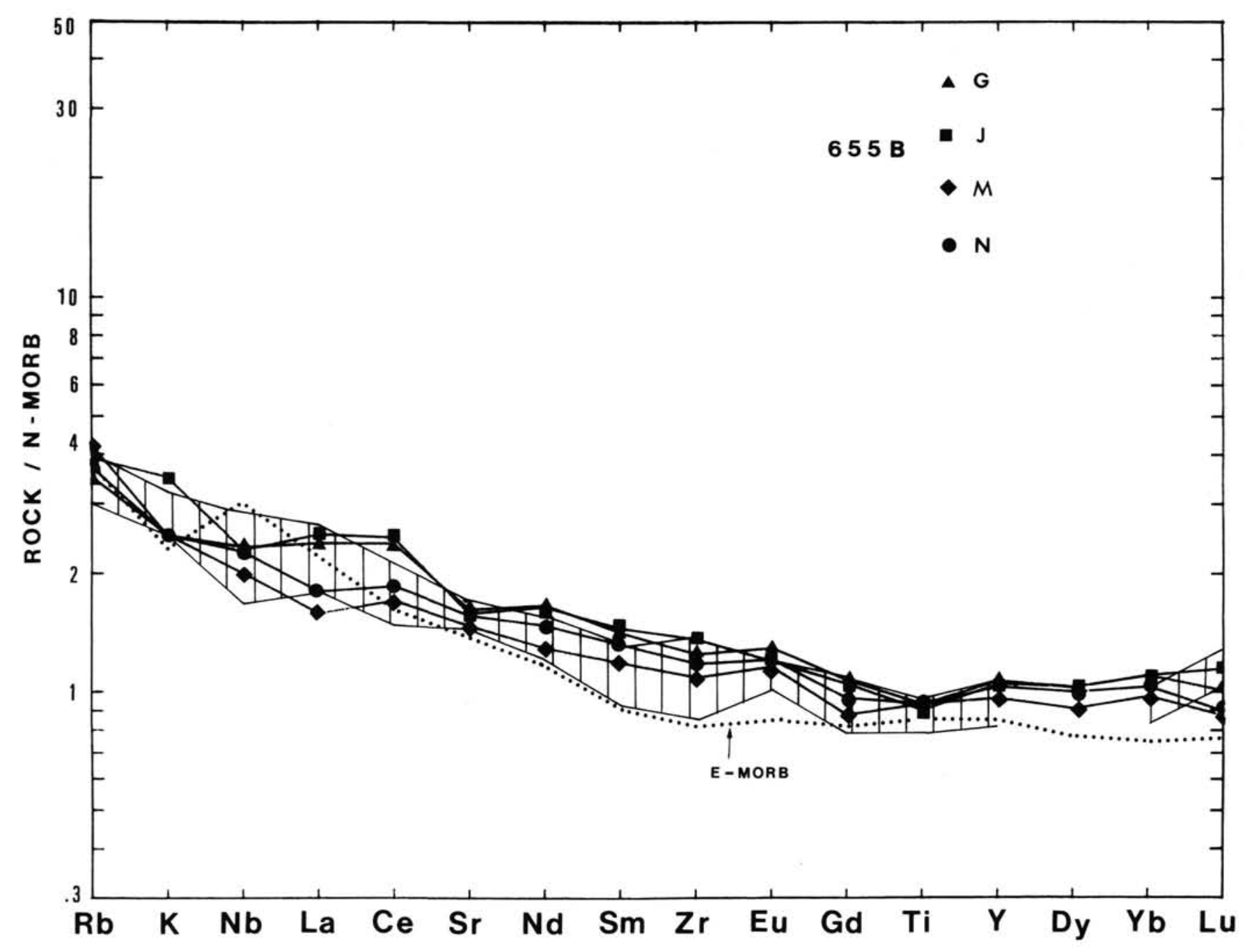

Figure 14. Hygromagmaphile element spidergrams of basalts from ODP Hole 655B normalized to N-MORB (average of Sun et al., 1979). Elements are arranged according to Thompson et al., 1982. Hachured pattern corresponds to basalts from high-Ti group Site 373 of DSDP Leg 42 (Barberi et al., 1978). Dotted pattern = E-MORB (average of Sun et al., 1979). 


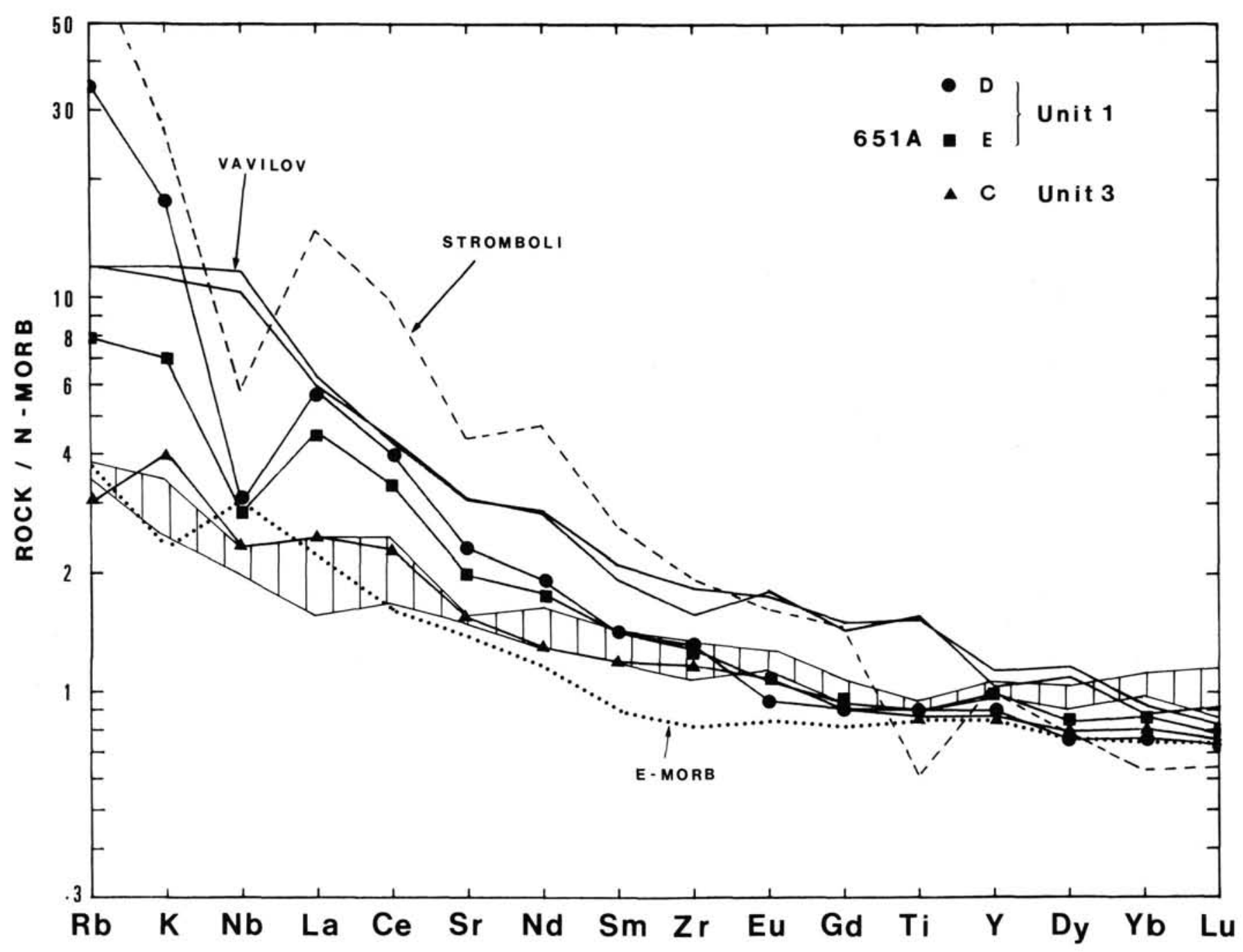

Figure 15. Hygromagmaphile element spidergrams of basalts from ODP Hole 651A normalized to N-MORB (same parameters as in Fig. 14). The whole pattern of Hole 655B basalts is also presented (hachured area). E-MORB average, basalts from Vavilov seamount (Robin et al., 1987), and a representative calc-alkaline andesite from Stromboli (Luais, 1986) are also plotted for comparison. 


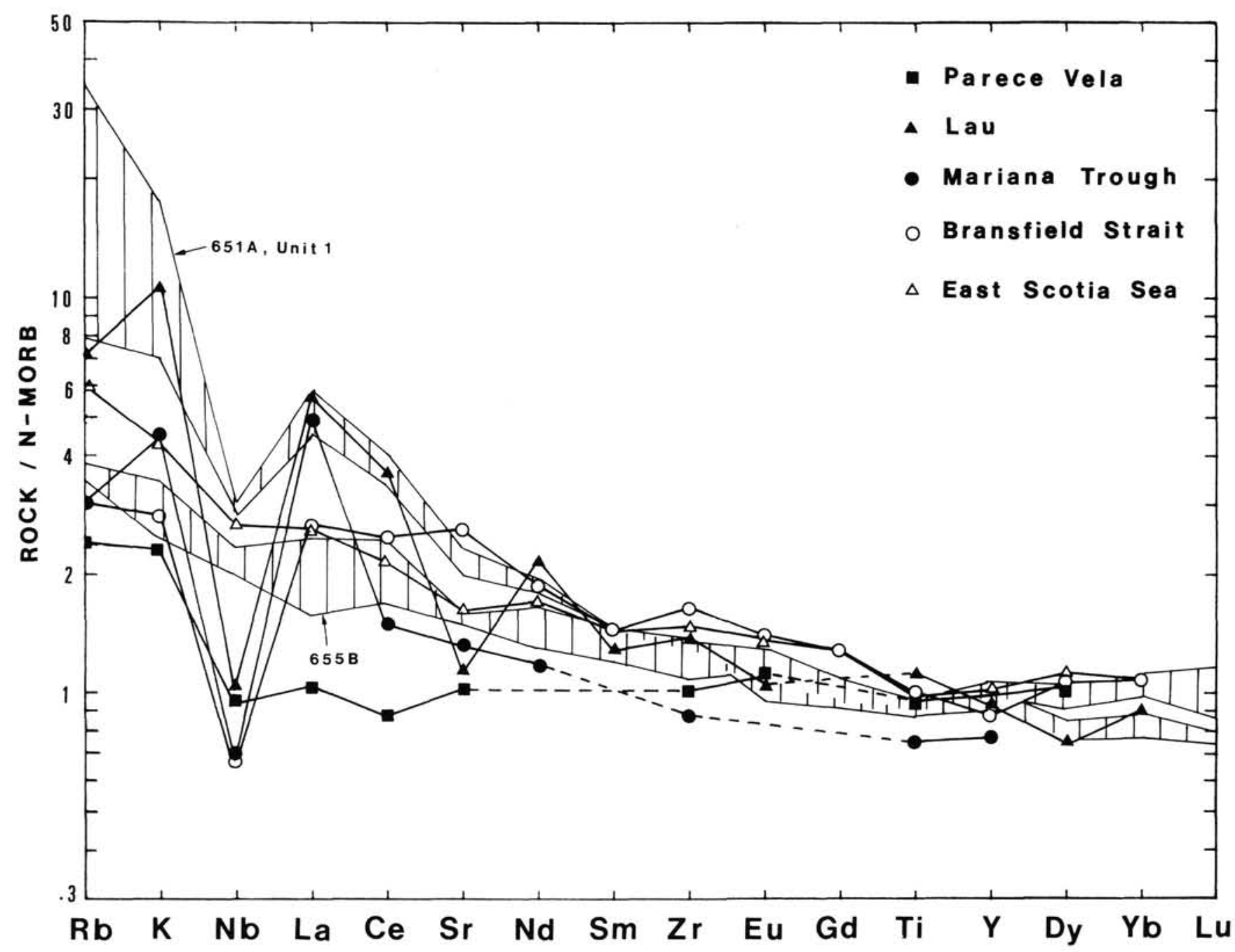

Figure 16. Representative spidergrams of reference back-arc basalts: from Parece Basin (Wood et al., 1981), Lau Basin (Gill, 1976), Mariana Trough (Wood et al., 1982), Bransfield Strait (Weaver et al., 1979), and East Scotia Sea (Saunders and Tarney, 1979). The respective fields of Hole 655B and Hole 651A (Upper Unit) are hachured. Normalizing parameters as in Figure 14. 